\title{
The Fairytale of Nicolas Denisot and the Seymour Sisters
}

\author{
HARRY VREDEVELD
}

Skeptical voices notwithstanding, Anne, Margaret, and Jane Seymour are still widely assumed to have written the Hecatodistichon (1550), a set of 104 Latin distichs memorializing Queen Marguerite of Navarre. The story of their authorship goes back to the girls' sometime tutor, Nicolas Denisot (1515-1559). His account, however, must be understood as a kind of fairytale in which the sisters are turned into princesses, while Denisot himself plays the wizard-tutor. The distichs' true author is Denisot. Proof comes from both internal and philological evidence. The work's sources, it turns out, are far too wide-ranging and recondite for beginning Latin pupils like the Seymours. Further proof is gleaned from comparing the Hecatodistichon with the manuscript that Denisot wrote on the death of Henry VIII and presented to Edward VI in early 1547. Both works draw on the same core of continental poets, in particular Tito and Ercole Strozzi and Helius Eobanus Hessus. ${ }^{*}$

\section{The Fairytale}

From the distance of centuries, the story has all the hallmarks of a reallife fairytale. In early winter $1546 / 47$ a poet-courtier by the name of Nicolas Denisot (1515-1559) leaves Paris under romantic circumstances and introduces himself to the English court. ${ }^{1}$ The obscure stranger proves to be a wizard. For after Henry VIII dies on 28 January 1547, the Frenchman quickly conjures up a memorial booklet in Latin verse and prose and presents his manuscript, exquisitely written on vellum, to the newly crowned Edward VI (reigned 1547-1553). Hereupon the king's uncle Edward Seymour (ca. 1500-1552) appoints him as tutor to his eldest daughters Anne (1538-1587), Margaret (born 1540), and Jane (1541-1561). ${ }^{2}$ At the time, the princesses are at most six, seven, and nine

\footnotetext{
* This article is much the better for the perceptive comments by the outside referees and the journal's editors. I am deeply grateful to all.

${ }^{1}$ On Denisot's life and works, see C. Jugé, Nicolas Denisot du Mans (1515-1559). Essai sur sa vie et ses æeuvres (Le Mans - Paris, 1907); R. Jousselin, Nicolas Denisot, poète de la Pléiade (Paris, 2006); J.-P. Barbier-Mueller, Dictionnaire des poètes français de la seconde moitié du XVIe siècle (1549-1615), vol. 2 (Genève, 2015), 443-450; D. Speziari, La plume et le pinceau. Nicolas Denisot, poète et artiste de la Renaissance (1515-1559) (Genève, 2016).

${ }^{2}$ See J.B. Stevenson, "Lady Jane Seymour (1541-1561)", in H.C.G. Matthew, B. Harrison (ed.), Oxford Dictionary of National Biography, vol. 49 (Oxford, 2004), 888-889.
} 
years old; but Denisot soon turns them into paragons of Latin verse. His task completed, the wizard vanishes in mid-1549 and returns to Paris. ${ }^{3}$ Early the next year, his little apprentices demonstrate that they can now match the master verse for verse. They jointly write 104 elegiac distichs to honor the late Marguerite of Navarre (1492-1549), whose Le Miroir de l'âme pécheresse Denisot has taught them to adore. Denisot learns of the girls' work and implores them to send him a copy. When he finally receives it in the early spring of 1550 , he publishes the verses under the title of Hecatodistichon. ${ }^{4}$ The sisters' epigrams are framed by rapturous letters to them from Denisot and his friend, the medical student Pierre des Mireurs. ${ }^{5}$ Paeans to the three English princesses and the deceased queen, written in Latin and Greek by different hands, round out the slim volume. Gratified by the book's success, Denisot brings out a revised and expanded edition in 1551 under the title Le Tombeau de Marguerite de Valois, Royne de Navarre. ${ }^{6}$ The book offers fresh encomiums by the finest young poets in the land as well as translations of the distichs into Greek, Italian, and French. Denisot is honored by his peers and made valet de chambre by the king. In England, meanwhile, the little princesses fall into a deep slumber and for centuries are forgotten by all. But at length released from their oblivion, they live to this day as pioneers of women's literature in England.

\section{Enchantment}

First sketched out in 1550 and embroidered ever since, the tale of the French wizard and the English princesses has so enchanted the modern imagination that even normally sober-minded scholars can see "no reason to doubt that the [Hecatodistichon] is substantially the work of the three

\footnotetext{
${ }^{3}$ For the date, see Ph.A. Becker, Aus Frankreichs Frührenaissance. Kritische Skizzen (München, 1927), 169; Jousselin 2006 (as in n. 1), 77.

${ }^{4}$ N. Denisot, Annae, Margaritae, Ianae, sororum virginum, heroidum Anglarum, In mortem Divae Margaritae Valesiae, Navarrorum reginae, Hecatodistichon. Accessit Petri Mirarii ad easdem virgines epistola, una cum doctorum aliquot virorum carminibus (Paris, 1550) [USTC 203780]; facsimile reprint in B.M. Hosington (ed.), Anne, Margaret, and Jane Seymour (Aldershot - Burlington, VT, 2000).

${ }^{5}$ On Pierre des Mireurs, see Barbier-Mueller 2015 (as in n. 1), 532-538.

${ }^{6}$ N. Denisot, Le Tombeau de Marguerite de Valois, Royne de Navarre. Faict premierement en disticques Latins par les trois Sœurs Princesses en Angleterre. Depuis traduictz en Grec, Italien, et François par plusieurs des excellentz poëtes de la France (Paris, 1551) [USTC 6757]; facsimile reprint in Hosington 2000 (as in n. 4).
} 
sisters." As such, the poem has been edited and translated no less than three times in the past few decades. ${ }^{8}$ It has been hailed as "the only published composition in Latin by any Englishwomen in the sixteenth century, the only one published in any language by any Englishwomen before the $1560 \mathrm{~s}$, and the first female-authored encomium written in England." Skeptical voices are raised from time to time too, but amidst the din of acclaim they have had a rather hard time of it. Already in 1927, Philipp A. Becker wonders how Denisot could have carried on a correspondence with the Seymours in early 1550, when France and England were at war, or how the girls could have calmly discoursed on the death of a French queen, whom they did not know, even as their father was being held in the Tower of London on charges of treason and felony and condemned to forfeit all his possessions. Then, too, Becker asks, how is it that the sisters would never again write anything of a literary nature? Why did no one in England remember them until the eighteenth century, after Pierre Bayle's Dictionaire historique et critique brought them back to light? Is it not far more likely that Denisot invented the story to lend an exotic air to an otherwise pedestrian poem? If so, Becker notes, "the conclusion seems to impose itself inescapably that we are dealing with an enormous fraud." 10 In recent years, the dissertation writers Amaury Flégès and Daniele Speziari have echoed and amplified Becker's doubts, both of them seeing Denisot as an ambitious self-promoter hiding behind a mask. ${ }^{11}$

Curiously, the skeptics' forlorn battle with the true believers is foreshadowed already in the 1550 volume. Even more curiously, one can observe it being fought out in the breast of Denisot's confidant Pierre des Mireurs. Most curiously of all, des Mireurs confesses to the internal struggle in his letter to the Seymours, printed directly on the heels of the Hecatodistichon itself. ${ }^{12}$

${ }^{7} \mathrm{Ph}$. Ford, The Judgment of Palaemon. The Contest between Neo-Latin and Vernacular Poetry in Renaissance France (Leiden - Boston, MA, 2013), 134; repeated in BarbierMueller 2015 (as in n. 1), 447: "Il n'y a pas de raison de douter de la paternité de ces vers."

${ }^{8}$ For a text, with notes, see Appendix B below.

9 B.M. Hosington, "England's First Female-Authored Encomium: The Seymour Sisters' Hecatodistichon (1550) to Marguerite de Navarre. Text, Translation, Notes, and Commentary", Studies in Philology 93.2 (1996), 117-163.

10 See Becker 1927 (as in n. 3), 170-171; cf. I.D. McFarlane, "Jean Salmon Macrin (1490-1557) (fin)”, Bibliothèque d'Humanisme et Renaissance 22.1 (1960), 73-89, at 77.

11 A. Flégès, Les tombeaux littéraires en France à la Renaissance, 1500-1589 (Tours, 2000), 364-366; Speziari 2016 (as in n. 1), 176-196.

12 Denisot 1550 (as in n. 4), f. b3r-b8r, at b3r-b4r. Cf. Speziari 2016 (as in n. 1), 195-196. 
Reverently addressing the sisters as maiden heroines equally remarkable for nobility and piety, des Mireurs starts off by lamenting his inadequacy in lauding the sisters' genius, all but on a par with Homer's. ${ }^{13}$ Only then does he recount his first reaction to hearing about the girl prodigies. Denisot, he explains, is not only a scholar favored of the gods, born for the Muses and Graces, but also a man of wit, much given to practical jokes. Hence, when his friend first told him about the divinely gifted sisters he had tutored at the English court, he, des Mireurs, instinctively dismissed the tale as a cock-and-bull story straight out of Lucian's True Histories: "Who, I ask, except someone who, in easy credulity, has been deluded into false persuasion, could possibly believe that genteelly educated girls - all the more at an age when they are almost totally absorbed in adorning and perfecting the body - could be the equals, not to say the superiors, of illustrious men in excellence and dignity?"14 Such marvelous attainment in such youthful girls, he concludes, is quite simply not to be believed (non verisimile), especially not in a day and age like ours when noblemen would rather marry their daughters off to some handsome and wealthy match than educate them in the liberal arts. ${ }^{15}$ If the skeptic in des Mireurs is finally won over by Denisot's assurances, it is only after his friend confronts him with evidence in the form of a manuscript of the Hecatodistichon, "elegantly written out in his own hand, but composed by you three sisters in

${ }^{13}$ Des Mireurs' language is modeled (tongue in cheek) on Angelo Poliziano's praise of Homer's genius. Compare his exordium (f. b3r): "Scripturus ad vos virgines tres sorores $[\ldots]$ doctrina et eruditione $[\ldots]$ claras, $[\ldots]$ sentio maiore eloquentia opus esse quae vel mihi [...] animi aviditatem explere queat vel exactissimo denique vestro iudicio atque eruditissimis auribus satisfacere", with the exordium of "Oratio in expositione Homeri" in Poliziano, Omnia opera (Venezia, 1498) [USTC 991842], f. \&1r: "Dicturus de Homero vate, doctrinarum omnium adque ingeniorum auctore et principe [...], sentio nullam eloquentiam nec optari nec concipi posse quae vel aviditatem animi nostri expleat $[\ldots]$ vel acerrimo denique iudicio vestro adque eruditissimis auribus satisfaciat." On f. b5v-b6r, des Mireurs continues: "Vestra [...] divina carmina, virgines, effecerunt ut in Margarita nostra posteritas virtutum omnium exempla, omnium rerum divinarum simulachra effigiesque intueatur [...]. Quid dicam quanta quamque indicibili facundia reginae invicti animi magnitudinem et rectum illum excelsumque divinitatis sensum expressum ante oculos constituant?" Here too des Mireurs takes his cue from Poliziano's oration on Homer (f. \&2r): "Quo effectum est ut in Homeri poesi virtutum omnium $[. .$.$] exempla, [\ldots]$ omnium rerum humanarum simulacra effigiesque intueamur ipsaque illa nobis expressa expromptaque ante oculos constituerit."

${ }^{14}$ Denisot 1550 (as in n. 4), f. b3v: "Quis, quaeso, nisi facili credulitate in falsam persuasionem prolapsus, puellas molliter educatas, eaque maxime aetate quae ornando ac perpoliendo corpori fere tota insumitur, illustribus viris excellentia et dignitate pares esse, ne dicam superiores, crediderit?"

${ }^{15}$ Denisot 1550 (as in n. 4), f. b4r. 
alternation". ${ }^{16}$ Thereupon, des Mireurs recalls, Denisot affirmed that the girls had been great admirers of the late queen of Navarre. They had so avidly studied Marguerite's divine poems, even though written in French, that they had memorized them word for word and lovingly inscribed them into their hearts. That is the reason why they had sought to honor her death with Latin distichs. Moved to tears by the sweet beauty, tender piety, and ineffable eloquence of the maidens' verses, des Mireurs abandons his disbelief. He congratulates the sisters on their wondrous refinement and erudition and places them high above the women poets of ancient times, even above the modern Cassandra Fedele. ${ }^{17}$

\section{Breaking the Spell}

What are we to make of des Mireurs' inner debate, with its protestation of incredulity followed by awed surrender to the story's charm? Seen within the context of the book as a whole, where it serves as an obvious pendant to Denisot's preface, the presentation certainly has all the look of a rhetorical ploy in which the reader is first confronted with the account's implausibility and then, as if by an illusionist's sleight of hand, is made to believe the unbelievable. For the fact remains that, no matter how much des Mireurs may twist and turn, the fanciful tale is vouched for by nothing more than Denisot's say-so, not by any hard evidence - at least not evidence of the sort that can withstand scrutiny. The manuscript that Denisot showed to des Mireurs most definitely does not fit the bill. It was just a copy, "elegantly written out in his own hand". Had Denisot really wanted to clinch the case with his wavering friend, he of course had only to produce the original that the Seymour sisters had allegedly sent him after much entreaty. But because he fails not only to produce the document but also to account for its absence, there can be only one conclusion: there never was such a manuscript. And if this is so, it follows like day upon night that the poem that Denisot wrote out in his own hand was not composed by the Seymour sisters. Their role in the book is a literary fiction. ${ }^{18}$

\footnotetext{
${ }^{16}$ Denisot 1550 (as in n. 4), f. b4v: "sua manu eleganter exscriptum, sed a vobis tribus sororibus $[\ldots]$ alternis $[\ldots]$ factum."

${ }^{17}$ Denisot 1550 (as in n. 4), f. b7r. Cf. note 23 below.

${ }^{18}$ Cf. Speziari 2016 (as in n. 1), 195-196.
} 
We are now well positioned to scrutinize Denisot's preface, which, like des Mireurs' contribution, is cast in the form of a letter to "the most illustrious princesses, the Seymour sisters Anne, Margaret, Jane”. Right from the start, Denisot makes a point of vaunting himself as his pupils' spiritual father, and by extension, as the spiritual author of their funerary poem. He embraces the girls' epigrams with all the love that "grandparents feel toward their grandchildren", a love, he insists, that is as strong as that of parents toward their own progeny. Accordingly, Denisot continues, "when I heard that you, too, had honored the recent death of the queen of Navarre not merely with tears but also with a hundred alternating distichs, I made it my highest priority first to solicit those verses by numerous letters and then, after receiving them, to cherish them as my dearest little grandchildren." He concludes that he has every right to regard his pupils' verses as his own offspring: "Seeing that I for my part $[. .$.$] both molded and educated you prodigies and those most$ noble-spirited minds of yours in poetry and my native letters, very much as a second father (even though your teacher John Crane, an adept in both tongues, amply imparted the rest, as befits his learning and diligence), I now acknowledge and embrace the verselets you brought forth as a second offspring, so to speak, of my own feeble talent, as an ornament as well as a delight to me no less than to you." Hence, Denisot continues, "as soon as I read them, I could not help but arrange to bring them out before the public, if not as my own, then certainly as the children I have in common with you, esteeming them assuredly not unworthy either of your brilliance as my pupils or of my work as your humble tutor, now that they are about to reach the hands of men." 19

Because we have been reading the little volume from back to front, so to speak, it is easy enough to see that Denisot's repeated claims to spiritual paternity are in fact meant to intimate his own authorship of the Hecatodistichon. ${ }^{20}$ Less easy to see is that Denisot, like des Mireurs, is playing a game in which he, magician-like, dupes the skeptical reader into accepting the fairytale as historical truth. Indeed, the very foregrounding of his claim to paternity is itself a trick aimed at diverting attention from the tricks that the illusionist is performing in the background.

\footnotetext{
19 Appendix B 1.1-5.

${ }^{20}$ See Speziari 2016 (as in n. 1), 195, following Flégès 2000 (as in n. 11), 349.
} 
For starters, in a classic fairytale touch, Denisot insists on addressing the sisters as "most illustrious princesses", as if they were royalty like Marguerite of Navarre. ${ }^{21}$ In point of fact, the girls were not princesses of the blood royal. They were the daughters of Duke Edward Seymour, the elder brother of Henry VIII's third wife, Jane Seymour. As such, they were entitled to be called "Lady", not "Princess". 22 Having thus, by legerdemain, turned the sisters into princesses, Denisot next transforms them into prodigies of Latin verse, for which achievement he, as their old tutor, proudly takes credit. But that feat of wizardry too is accomplished entirely through a trick of illusion. At no point does Denisot ever claim to have taught the girls Latin. He says only that he instructed them "in poetry and my native letters", that is to say, French language and literature, including verse. As for his colleague John Crane, Denisot brushes him aside in a parenthetical compliment as "an adept in both tongues" who taught the other subjects. Which other subjects? Well, since Denisot gave only French lessons, Crane must have tutored the girls, among other subjects, in Latin and (presumably) Greek. Thus it was Crane who could have rightly claimed paternity of the Seymour's verses - had these verses actually been theirs and not Denisot's. This conclusion, neatly glossed over in Denisot's letter and hence readily overlooked, is asserted with brutal plainness in des Mireurs' letter. After praising the girls' parents for wanting their daughters to be educated so wonderfully well, des Mireurs adds: "On that score I also heartily congratulate your teacher John Crane, a man (as I understand from the same Denisot and the report of many others) deeply versed in both tongues and most diligent in forming, tending, and instructing your adolescence. Truly, the greatest honor is due to his generous-spirited labor, greater in fact than if he had undertaken to train ten Cleobulinas, Cornificias, Corinnas, Lesbias, not to mention Cassandra Fedele of Venice, so highly celebrated by Poliziano, as poetesses." 23 The homage

${ }^{21}$ The salutation is addressed to "Illustrissimis Principibus". At sentence 5, the sisters' verses are said to be "ita scripti ut et in nobilissimam reginam a nobilissimis regis consobrinis et in piissimam ac doctissimam principem a piissimis doctissimisque principibus puellis luculentius atque suavius scribi non potuerint." At sentence 10 they are addressed as "ter geminae sororculae Principes".

${ }^{22}$ Already noted by Pierre Bayle, Projet et fragmens d'un dictionaire critique (Rotterdam, 1692), 367, under the heading "Seymour (Anne, Marguerite, et Jeanne)"; reaffirmed in his Dictionaire historique et critique, vol. 2.2 (Rotterdam, 1697), 1037.

${ }^{23}$ Denisot 1550 (as in n. 4), f. b7r: "Gratulor et eo nomine plurimum Ioanni Cranno praeceptori vestro, viro (ut ex eiusdem Denisoti ac multorum sermone accepi) in utraque 
to John Crane is repeated in the book's second edition (1551) by Nicolas de Herberay des Essarts (died ca. 1552). There we learn that the three sisters possessed, among other grand qualities, "the spirit of Socrates, the tongue of Homer, and the elegant writing style (le bien-escripre) of their teacher Crane". ${ }^{24}$

The story of the wizard and the three princesses, then, is a fiction, cast in the form of a fairytale and insinuated entirely through sleights of hand. As the breathlessly hyperbolic letters from Pierre des Mireurs and Nicolas de Herberay suggest, however, the fiction was always intended to be understood as such, by the insiders at least. ${ }^{25}$ To the likes of Charles de Sainte-Marthe (1512-1555) and Jean Dorat (1508-1588), the conceit must have seemed enchanting indeed: three English princesses painting an admiring portrait of a deceased French queen, three pious young poetesses paying tribute to a great Christian poetess, three Sirens of the British shore beckoning the poets of France to emulation. And emulate they did, those French poets, some by mourning the late queen of Navarre, others by extolling her young English admirers. So successful was the game that Denisot was able to recruit even more players in 1551, among them the rising stars of the future Pléiade: Joachim du Bellay (ca. 1522-1560), Pierre de Ronsard (1524-1585), and JeanAntoine de Baiff (1532-1589). ${ }^{26}$ What none of the co-players in this fiction could know, however, was that their illusionist friend had reserved his last trick for them: he had rigged the game. For even as they earnestly vied with each other for the prize of renown, they were unknowingly handing it to the game's organizer and director, Nicolas Denisot. In his dedicatory letter he had forged an image of himself as a

lingua exercitatissimo et in formanda, curanda, erudienda adolescentia vestra diligentissimo. Maximus profecto eius tam generoso labori honos debetur, maiorque quam si decem Cleobulinas, Cornificias, Corinnas, Lesbias, adde his Cassandram Fidelem Venetam, a Politiano tantopere celebratam, poetrias in disciplinam suscepisset." Here des Mireurs outdoes Poliziano, who praises Cassandra Fedele as merely the equal of any of the ancient poetesses. For Poliziano's letter to Fedele, see S. Butler (ed., tr.), Angelo Poliziano, Letters (Cambridge, MA - London, 2006), 188-193. For an interpretation of that letter, see L. Jardine, "O decus Italiae virgo, or The Myth of the Learned Lady in the Renaissance", The Historical Journal 28.4 (1985), 799-819.

${ }^{24}$ Denisot 1551 (as in n. 6), f. A4r, in a mock epitaph modeled on the epitaph for Arete of Cyrene (fourth century BC).

${ }^{25}$ Speziari 2016 (as in n. 1), 194, agrees: "On peut croire que les poètes réunis autour de Denisot n'étaient pas dupes et qu'au contraire ils ont été plus ou moins complices de cette supercherie."

${ }^{26}$ For a detailed analysis of the 1551 edition, see Ford 2013 (as in n. 7), 131-147. 
tutor sans pareil, a wizard who turned his youthful pupils into sophisticated poetesses. Now, in a final triumph, he had enlisted the leading poets of France to laud his own epigrams as a divine creation, a song of the very Graces and Sirens.

It was not the first time Denisot had played the wizard to advance his career.

\section{The Commemorative Manuscript of 1547 (London, British Library, ms. Royal 12 A VII)}

In late 1546 or early 1547, Denisot left the comforts of Paris and introduced himself to the English court as a man whose love for a lady of quality had earned him jealousy and a death threat. To all appearances, the romantic story was just a cover for his true mission in England: to serve as a secret agent of France. ${ }^{27}$ Denisot was supremely qualified for the task. In the preceding year or two he had moved easily at the court of France; ${ }^{28}$ he would be able to do the same in England. Moreover, he was what we would nowadays call a Renaissance man: a painter, calligrapher, and cartographer, a poet in his native French, a man of letters fluent in Latin. He would make a fine tutor in some high noble family. First, however, he would have to make a name for himself at court. Thus, when Henry VIII died on January 28, Denisot seized the moment to put together a booklet in Latin prose and verse mourning the royal death and saluting the coronation of the boy king Edward VI on February $20 .{ }^{29}$ When he was done, he copied out the work on vellum in his own elegant hand and presented the manuscript, adorned with gold and silver, to the newly crowned king. ${ }^{30}$ The homage, so speedily and generously given, had its intended effect. Denisot was appointed French tutor to the three eldest daughters of Edward Seymour, the king's uncle and now Lord Protector of the realm. To a spy like Denisot, the tutorship

\footnotetext{
27 See Jugé 1907 (as in n. 1), 57-58, 147-148; Speziari 2016 (as in n. 1), 36-38.

${ }^{28}$ See Jousselin 2006 (as in n. 1), 47-48, 51-52; Speziari 2016 (as in n. 1), 39.

29 For this scenario, see Speziari 2016 (as in n. 1), 38-39. For a description of the manuscript, see the record in the British Library's Catalogue of Illuminated Manuscripts; Speziari 2016 (as in n. 1), 149-165. For a text of the manuscript, see Appendix A.

30 Cf. Speziari 2016 (as in n. 1), 149. The reasonable surmise that Denisot, as an excellent calligrapher, would have personally prepared the manuscript, finds support on f. $27 \mathrm{v}$ (Oceani Britannici plausus, 71), where the slip of the pen "longua" for "longa" is natural enough for a Frenchman, but not for an English scribe.
} 
must have seemed a dream position. For a few hours each week he would instruct the Seymour sisters in French. The rest of the time he was free to keep his eyes and ears open at court or, if need be, to make clandestine maps and forge documents.

The magnificent 68-page manuscript that Denisot formally offered to Edward VI was duly shelved with other such treasures in the king's collection. There it remained until 1757, when George II presented the Old Royal Library to the British Museum. The manuscript is now in the British Library, London, as ms. Royal 12 A VII (henceforth R). It is structured as follows:

1. Ad librum (f. 1r-2r), in elegiac distichs. The poet urges his book to hurry to the new king, who, he trusts, will not disdain a humble gift.

2. Acclamatio in funere Henrici Octavi (f. 3r-8r). This is a prose eulogy for Henry VIII, introduced by eight dactylic hexameters.

3. Aegloga, quae Amaryllis dicitur, super immatura morte Regis Henrici (f. 9r-14v), in dactylic hexameters. The nymph Amaryllis (England) laments the premature death of the shepherd Amyntas (Henry VIII), but draws hope from his children.

4. Henrici Octavi epicedium (f. 15r-24r), in elegiac distichs. The poet grieves for the death of Henry VIII, but rejoices in the knowledge that the king now lives with the saints in heaven. Two verse epitaphs follow, both in elegiacs.

5. Oceani Britannici plausus super ingressu Eduardi VI (f. 25r-28v), in dactylic hexameters. The personified British Ocean applauds the accession of Edward VI. At the end of the poem, the Ocean calls on the Thames River to follow his lead.

6. Temesus. Eduardus Sextus rex salutatus (f. 29r-34r), in elegiac distichs. The Thames River cheers the coronation of Edward VI.

\section{Patches from Other Men's Garments}

To the courtiers watching Denisot present his manuscript to Edward VI, the sumptuous tribute must have seemed pure wizardry. How could the obscure Frenchman have put together such an impressive work, in prose as well as verse, and then copy it out himself, in a beautiful hand, all in just a few short weeks? Had the erudite John Leland (ca. 1503-1552) 
been at court in those days, still in his wits, the astounded onlookers might have had their answer long since. For the truth is that the poems and prose that Denisot copied out so beautifully into $\mathbf{R}$ are little more than a splendid illusion: a magician's star-studded cloak that, exposed to the glare of day, reveals itself as a patchwork, rudely stitched together from other men's garments. ${ }^{31}$

The textual patches - often repetitious and redundant, ill-joined, stylistically incoherent, occasionally even grammatically incomplete or wrong - are plagiarized from a veritable who's who of Neo-Latin continental writers. The Italians are especially well represented: Giovanni Pontano (1426-1503), Tito Strozzi (1424-1505) and his son Ercole (died 1508), Jacopo Sannazaro (1456-1530), Fausto Andrelini (1462-1518), Pietro Bembo (1470-1547), Celio Calcagnini (1479-1541), Andrea Ammonio (ca. 1478-1517), Quinziano Stoa (1484-1557), and Gianbattista Giraldi Cinzio (1504-1573). Denisot must have been fond of the Germans too, in particular the "king of poets" Helius Eobanus Hessus (1488-1540) and his younger contemporary Georg Sabinus (1508-1560). Of the French Neo-Latinists, Denisot makes much use of Jean Voulté (ca. 1505-1542). The little-known Jean Arnollet also appears as an occasional source. ${ }^{32}$

Closer analysis of $\mathbf{R}$ yields the following pattern:

a) While Neo-Latin poets and prose writers typically borrow bits and pieces of text from their predecessors as they go about the business of creating new works, Denisot takes this practice to its plagiaristic extreme. Leaving imitation to the imitators, he copies out whole lines and paragraphs verbatim and cobbles them together, adapting them only as needed to fit their new context.

b) Virtually all the materials used in the manuscript come from books that were in print in the 1530s and 40s, at the very time that Denisot was building up his personal library: Strozii poetae pater et filius (Venezia, 1513; Paris, 1530), which includes Calcagnini's eulogy of Ercole Strozzi; Pontano's Carmina, quae quidem extant, omnia (Basel, 1531) [USTC 667391]; Sannazaro's Opera omnia (Venezia, 1535; Lyon, 1536; Lyon, 1540); Voulté's Oratio funebris de Iacobo Minutio Tholosae

31 The image comes from Eobanus Hessus, Oratio, sive praelectio in auspicio Officiorum M. Tullii Ciceronis et M. Accii Plauti comoediarum 10.2. See H. Vredeveld (ed., tr.), The Poetic Works of Helius Eobanus Hessus, vol. 3 (Leiden - Boston, MA, 2012), 96-97.

${ }^{32}$ For a detailed account of Denisot's borrowings, see Appendix A, notes. 
habita (Lyon, 1537) [USTC 147297] and Epigrammatum libri IIII (Lyon, 1537); Hessus' Operum farragines duae (Schwäbisch Hall, 1539); Giraldi's Poematia (Basel, 1544); Sabinus' Poemata (Strasbourg, 1538; Strasbourg, 1544); the anthology Poematia aliquot insignia illustrium poetarum recentiorum (Basel, 1544), with inter alia verses by Bembo, Quinziano Stoa, and Arnollet; also the anthology that Gilbert Cousin edited under the title En habes, lector, bucolicorum autores XXXVIII (Basel, 1546) [USTC 649941], with pastorals by Petrarch, Andrelini, Pontano, Ammonio, Hessus, Arnollet, and Sannazaro. ${ }^{33}$

c) Of the Neo-Latin poets used, Eobanus Hessus, Tito and Ercole Strozzi, Giovanni Pontano, and Pietro Bembo head the list. Less commonly used are Sabinus, Voulté, Giraldi, Poliziano, Andrelini, Arnollet, and Sannazaro.

With this philological signature in hand, we now return to the Hecatodistichon.

\section{The Hecatodistichon of $\mathbf{1 5 5 0}$}

Fearing that he had been unmasked as a secret agent and forger of documents, Denisot hurriedly left England in June or early July 1549 and returned to Paris. ${ }^{34}$ There, just as in 1547, it was a royal death that would propel him back into the life of a littérateur. For after Marguerite of Navarre died on 21 December 1549, Charles de Sainte-Marthe recruited Denisot, des Mireurs, and other writers to contribute to his commemorative book on the death of Queen Marguerite, which appeared in Paris in mid-April $1550 .{ }^{35}$ Denisot's contribution was an elaborate prose epitaph, printed at the book's end in the form of a funerary plaque. ${ }^{36}$ Spurred by Sainte-Marthe's example, Denisot quickly resolved to put together a similar tumulus himself. ${ }^{37}$ The heart of this volume, as we have seen,

\footnotetext{
${ }^{33}$ For further information, see the references in the Appendix.

${ }^{34}$ Jugé 1907 (as in n. 1), 57-58; Jousselin 2006 (as in n. 1), 77-79; Speziari 2016 (as in n. 1), 38 .

${ }^{35}$ C. de Sainte-Marthe, In obitum incomparabilis Margaritae, illustrissimae Navarrorum reginae, oratio funebris (Paris, 1550) [USTC 150585].

${ }^{36}$ Sainte-Marthe 1550 (as in n. 35), f. t1v; the plaque is reprinted at the end of Denisot 1551 (as in n. 6), f. N8r. On Sainte-Marthe's book, published simultaneously with a French version, see M. Magnien, "Charles de Sainte-Marthe et son Oraison funebre de la mort de l'incomparable Marguerite, Royne de Navarre (1550)", Travaux de littérature 7 (1994), 65-90.

${ }^{37}$ Cf. Magnien 1994 (as in n. 36), 88-89; Speziari 2016 (as in n. 1), 174-177.
} 
would be a set of some one hundred distichs, to be ascribed to Denisot's former pupils in England. Denisot would sketch out the fiction in a prefatory letter to the Seymours, all the while letting his own authorship shine through. The other contributors, including Pierre des Mireurs and Charles de Sainte-Marthe, were invited to play along. The book was ready for the press in early May, shortly after the publication of SainteMarthe's Oratio funebris.

\section{Philological Signature}

Of course, Denisot could not but imprint his philological signature on the Hecatodistichon too, just as he had done in $\mathbf{R}$. The personal pattern shows up first in the prefatory epigram, where the poet, following up on the story of the Seymour prodigies, vents his immense joy upon receiving the girls' distichs. Half of this epigram is based on a poem in Eobanus Hessus' Sylvarum libri IX (1539). The other half is drawn from a poem in Janus Secundus' Epistolae (1541). The borrowed texts are altered and adapted to suit the new context. ${ }^{38}$

The Hecatodistichon proper exhibits the following characteristics:

a) Almost one half of the distichs contain texts lifted or adapted from continental Neo-Latin poets.

b) The remaining distichs appear to be of Denisot's own creation. Of these, most versify either funerary commonplaces or biblical and liturgical texts.

c) The most commonly used Neo-Latin poets are once again Eobanus Hessus and the two Strozzis, followed by Giraldi, Sannazaro, Poliziano, and Andrelini.

d) In nine instances, wording in the Hecatodistichon matches or recalls wording in $\mathbf{R}$ (distichs 6, 23, 37, 42, 46, 49, 53, 67, 76).

e) Janus Secundus and Baptista Mantuanus, not used as sources in $\mathbf{R}$, appear in both Denisot's prefatory epigram and the Hecatodistichon proper.

f) Three distichs in the Hecatodistichon are based on epitaphs in Catalogi duo operum Desiderii Erasmi Roterodami, printed at Antwerp and Basel in 1537 (distichs 19, 32, 35). ${ }^{39}$ Denisot does not use this source in $\mathbf{R}$.

\footnotetext{
38 See Appendix B, notes.

39 It would appear that the epitaphs are reprinted in Erasmus Roterodamus de lucubrationum suarum proventu et aliorum in se benignitate. Tumulorum et epitaphiorum libellus, in quo mors D. Erasmi [...] a studiosis defletur (Paris, 1537) [USTC 185852]; not seen.
} 
g) Two (perhaps three) distichs go back to Sainte-Marthe's just published Oratio funebris (distichs 40, 85, 89). Another distich versifies an expression in the funerary plaque for Queen Marguerite that Denisot himself contributed to Sainte-Marthe's book (distich 6).

\section{Conclusion}

It is now time to pull together the evidence uncovered in this article:

a) The letters that Denisot and des Mireurs address to the Seymour sisters in the 1550 edition are rhetorical fictions that portray Denisot as a wizard-tutor who has transformed three English princesses into prodigies of Latin verse. The fictions are intended not to deceive readers so much as delight them with a fairytale-like story. Several contributors to the tombeaux of 1550 and 1551 enhance the fiction by praising the sisters as the three Graces or as sweet-singing Sirens.

b) The philological signature gleaned from Denisot's prefatory epigram and the Hecatodistichon closely matches the signature observed in $\mathbf{R}$. While the 1550 texts advisedly steer clear of the rampant plagiarism of the 1547 manuscript, they often do incorporate chunks of text from earlier authors. The matching pattern points to a single author: Nicolas Denisot.

c) $\mathbf{R}$ and the Hecatodistichon draw on much the same core of continental authors, virtually all of whom were in print during the 1530s and $40 \mathrm{~s}$, in editions published in Paris, Lyon, and Basel and thus readily available to a French writer building up a personal library in those years. This evidence points to Denisot's authorship of the Hecatodistichon.

d) Eobanus Hessus and the two Strozzis head the list of authors used in both works. Other shared primary sources include Andrelini, Giraldi, and Sannazaro. The close match, especially in such an idiosyncratic list, is strong proof of Denisot's authorship of the Hecatodistichon.

e) The considerable overlap of borrowings between $\mathbf{R}$ and Hecatodistichon corroborates Denisot's authorship of the 104 memorial distichs.

f) Two sources not found in $\mathbf{R}$ crop up in both Denisot's prefatory epigram and the Hecatodistichon: Janus Secundus and Baptista Mantuanus. The shared sources corroborate Denisot's authorship of the distichs memorializing Marguerite of Navarre.

g) The repeated use of epitaphs on the death of Erasmus published in Catalogi duo operum Desiderii Erasmi Roterodami (1537) - a tome not 
likely to have been perused by beginning Latin pupils in England - is proof that the Seymour sisters did not write the distichs attributed to them. The same goes for Tito Strozzi's Eroticon libri VI, a book of amatory verse liberally quarried in both $\mathbf{R}$ and Hecatodistichon.

h) The linguistic, literary, and rhetorical sophistication displayed in the Hecatodistichon as well as the author's obvious familiarity with a wide array of continental poets place the epigrams far beyond the ken of beginning Latin pupils in England, or, far that matter, anywhere in Europe. They point to an experienced writer like Denisot, not to preadolescent tyros.

i) The adaptation of several texts in Sainte-Marthe's Oratio funebris is further proof that the Seymour sisters did not compose the 104 distichs of the Hecatodistichon. Sainte-Marthe's book, it should be recalled, came out in the latter half of April 1550, a month or two after Anne, Margaret, and Jane supposedly wrote their tributes to the Queen of Navarre. At the end of his letter to the Seymours, dated 30 April 1550 , Pierre des Mireurs confirms that the sisters could not yet have seen the just published book: "In very much the same vein as you, my great friend [...] Charles de Sainte-Marthe has written a funeral oration on the queen's death. Our dear Denisot has promised to send it to you, in both the Latin and French version." 40

To conclude, therefore: the three English princesses, those virgin Graces and Sirens of the British shore, never did exist in real life. They are fairytale characters created by Nicolas Denisot. Denisot, for his part, was no wizard. Acting as a secret agent and forger in England in 1547, he passed off as his own work a manuscript consisting of texts written (almost wholly) by others. Restarting his career as a littérateur in Paris in 1550 , he then presented as the work of others a poem that was (only partly) his own. But that was Denisot's way. Instead of painstakingly gathering his honey from the flowers of ancient and modern verse, as other poets did, he did not scruple to raid it ready made from the nearest hives, confident that in his illusionist's cloak he would not soon get stung.

40 Denisot 1550 (as in n. 4), f. b8r: "Scripsit eodem quo et vos argumento in reginae obitum orationem funebrem C. Sanctomarthanus, amicus summus meus [...]. Hanc Latinam et Gallicam se ad vos missurum Denisotus noster est pollicitus." 


\section{Appendix: Editions}

The reference editions of the texts cited in the notes to the editions are:

Ammonio, Carmina

C. Pizzi (ed.), Andrea Ammonio, Carmina omnia. Accedunt tres epistolae nondum editae (Firenze, 1958).

Andrelini, Bucolica

Fausto Andrelini, Bucolica, in W.P. Mustard (ed.), The Eclogues of Faustus Andrelinus and Ioannes Arnolletus (Baltimore, MD, 1918), 23-66.

Arnollet, Bucolica

Jean Arnollet, Bucolica, ibidem, 91-106.

Bourbon, Nugae

Nicolas Bourbon, Nugae (Paris, 1533) [USTC 138189].

Calcagnini, Oratio

Celio Calcagnini, Oratio tumultuario habita in funere Herculis Strozae, in Strozii poetae, f. $255 \mathrm{r}-259 \mathrm{v}$.

Erasmus, Catalogi

Catalogi duo operum Des. Erasmi Roterodami ab ipso conscripti et digesti (Antwerpen, 1537; Basel, 1537) [USTC 441706, 619712]. Cited after the Basel reprint.

Giraldi, Poematia

Giovanni Battista Giraldi Cinzio, Poematia (Basel, 1540) [USTC 625835].

Hessus, Eccles.

Helius Eobanus Hessus, Ecclesiae afflictae epistola ad Lutherum, in H. Vredeveld (ed., tr.), The Poetic Works of Helius Eobanus Hessus, vol. 4 (Leiden Boston, MA, 2016), 278-305.

Hessus, Epicedia

Helius Eobanus Hessus, Illustrium ac clarorum aliquot virorum memoriae scripta epicedia XII [sic], in Hessus, Farragines, part 1, f. 145v-178r; H. Vredeveld (ed., tr.), Helius Eobanus Hessus, Dichtungen. Lateinisch und Deutsch, vol. 3 (Bern - Frankfurt am Main - New York, NY - Paris, 1990), 103-181 (=Epicedia 1-9), 485-499 (=Epicedium 10), 541-551 (=Epicedium 11).

Hessus, Farragines

Helius Eobanus Hessus, Operum farragines duae (Schwäbisch Hall, 1539) [USTC 679718]. Except for the Theocritus translation and the Psalm paraphrases, all the Hessus texts used by Denisot are taken from this volume.

Hessus, Idyl.

Helius Eobanus Hessus, Bucolicorum idyllia XVII, in Hessus, Farragines, part 1, f. 2r-55r; H. Vredeveld (ed., tr.), The Poetic Works of Helius Eobanus Hessus, vol. 5 [in preparation]. 
Hessus, Luth.

Helius Eobanus Hessus, In evangelici Doctoris Martini Lutheri laudem defensionemque elegiae IIII, in H. Vredeveld (ed., tr.), The Poetic Works of Helius Eobanus Hessus, vol. 4 (Leiden - Boston, MA, 2016), 222-263.

Hessus, Psalt.

M. Fuchs (ed.), Helius Eobanus Hessus, Psalterium universum (Berlin, 2009).

Hessus, Sylv.

Helius Eobanus Hessus, Sylvarum libri IX, in Hessus, Farragines, part 1, f. 179r-340r; H. Vredeveld (ed., tr.), The Poetic Works of Helius Eobanus Hessus, vol. 8 [in preparation].

Hessus, Theoc.

Helius Eobanus Hessus, Theocriti Syracusani Idyllia triginta sex, Latino carmine reddita (Hagenau, 1531).

Hessus, Wirt.

Helius Eobanus Hessus, De victoria Wirtembergensi, in H. Vredeveld (ed., tr.), Helius Eobanus Hessus, Dichtungen. Lateinisch und Deutsch, vol. 3 (Bern Frankfurt am Main - New York, NY - Paris, 1990), 503-539.

More, Epigr.

C.H. Miller et al. (ed.), The Complete Works of St. Thomas More, vol. 3.2: Latin Poems (New Haven, CT - London, 1984).

Petrarch, Ecl.

M. François, P. Bachmann (ed., tr.), Francesco Petrarca, Bucolicum carmen (Paris, 2001).

Poematia aliquot

Poematia aliquot insignia illustrium poetarum recentiorum (Basel, 1544) [USTC 684539].

Poliziano, Eleg.

Angelo Poliziano, Elegiae, in I. del Lungo (ed.), Prose volgari inedite e poesie latine e greche edite e inedite di Angelo Ambrogini Poliziano (Firenze, 1867), 227-256.

Poliziano, Epigr.

Angelo Poliziano, Epigrammata Latina, ibidem, 109-166.

Pontano, Ecl.

Giovanni Pontano, Eclogae, in J. Oeschger (ed.), Ioannis Ioviani Pontani carmina: Ecloghe - Elegie - Liriche (Bari, 1948), 3-62.

Pontano, Eridanus

Giovanni Pontano, Eridanus, ibidem, 381-444.

Sabinus, Eleg.

Georg Sabinus, Elegiarum libri IIII, in Sabinus, Poemata, f. A2r-I7v. 
Sabinus, Poemata

Georg Sabinus, Poemata, ab authore recens aucta et recognita (Strasbourg, 1544) [USTC 659428].

Sannazaro, Ecl.

Jacopo Sannazaro, Piscatoriae eclogae, in M.C.J. Putnam (ed., tr.), Jacopo Sannazaro. Latin Poetry (Cambridge, MA - London, 2009), 102-141.

Sannazaro, Epigr.

Jacopo Sannazaro, Epigrammaton libri tres, ibidem, 252-361.

Sannazaro, Virg.

Jacopo Sannazaro, De partu Virginis libri tres, ibidem, 2-93.

Secundus, $E p$.

Janus Secundus, Epistolae, in P. Bosscha (ed.), Ioannis Nicolaii Secundi Hagani Opera omnia, vol. 2 (Leiden, 1821), 25-96.

Strozii poetae

Tito Strozzi, Ercole Strozzi, Strozii poetae pater et filius (Venezia, 1513; Paris, 1530) [USTC 857690, 146210], cited according to the Paris reprint as the edition that Denisot would most likely have used.

Strozzi, Aeolost.

Tito Strozzi, Aeolostichon libri IIII, in Strozii poetae, f. 188v-236v.

Strozzi, Am.

Ercole Strozzi, Amorum libri II, ibidem, f. 63v-84r.

Strozzi, Epigr.

Ercole Strozzi, Epigrammata, ibidem, f. 84v-97r.

Strozzi, Erot.

Tito Strozzi, Eroticon libri VI, ibidem, f. 102r-188v; numbering (where applicable) taken from A. della Guardia (ed.), Tito Vespasiano Strozzi. Poesie latine tratte dall'Aldina e confrontate coi codici (Modena, 1916), 1-179.

Voulté, Epigr.

Jean Voulté, Epigrammatum libri IIII. Xenia (Lyon, 1537) [USTC 147250].

Voulté, Oratio

Jean Voulté, Oratio funebris de Iac. Minutio Tholosae habita, in L. Dorez, "Le manuscrit de Dante offert au Roi François Ier en 1519 par Jacques Minut, président aux Parlements de Bordeaux et de Toulouse", Revue des bibliothèques 13 (1903), 207-223, at 212-219. 


\section{A. London, British Library, ms. Royal 12 A VII (R)}

Despite its centrality to Denisot's oeuvre, the manuscript has never before been published in its entirety. ${ }^{41}$

The texts have been edited from digital photographs supplied by the British Library. I modernize the punctuation, normalize to some extent the use of $u / v$, ae/oe/e, $c / t, i / j$, and $i / y$, expand abbreviations and ligatures, and adjust the capitalization and paragraphing. Diacritical marks are omitted. In his precipitous haste, Denisot made numerous copying errors. I correct such errors from Denisot's sources or, in doubtful cases, indicate the source's wording; see the critical apparatus. Words and letters omitted in the manuscript have been supplied within angle brackets, likewise from Denisot's sources.

In keeping with the focus of this study, the notes aim only to identify Denisot's primary sources, not to elucidate the texts themselves or to discuss precisely how Denisot adapts or combines his source texts.

\section{Ad librum}

Vade, liber, gratas EDUARDI Regis ad aures, uberior per quem Gorgonis unda fluit,

nec vereare, licet magnis ego vatibus impar nec biberim latices, Aonis unda, tuos.

Scis tamen ut nostras Musae, mea gaudia Musae, 5 non dedignatae cingere fronde comas.

Vade igitur, nec te properantem maxima tardent atria, magnanimi nobile regis opus,

et cave ne pictis radians laquearibus aurum spectanti longae sit tibi causa morae.

Ad regem propera. Quem postquam videris, illi caetera postpones quae preciosa putas.

Ille quidem facilis, nec te, nisi fallor, euntem despiciet, placida suscipietque manu.

1 - 1 The poem's core is taken from Strozzi, Erot. 1.1 ("Adloquitur librum"), addressed to Duke Ercole I d'Este (r. 1471-1505). | Vade ... 8 opus: from Strozzi, Erot. 1.1-8. | Vade ... 2 fluit: cf. Johann Stigel, in Sabinus, Poemata, f. R4v: "Ite [...] vatis ad aures, / uberius per quem Gorgonis unda fluit."

5 Musae ... Musae: cf. Hessus, Idyl. 2.14 (refrain): "Musae [...] mea gaudia Musae."

9 et cave ... 16 novo: from Strozzi, Erot. 1.1.37-40, 43-44, 57-58.

41 For a literary appreciation, without knowledge of the booklet's true sources, see Jugé 1907 (as in n. 1), 47-55; Speziari 2016 (as in n. 1), 149-165. 
Oscula cum dederis felici debita dextrae, sis memor haec regi dicere verba novo:

"Haec age, pacifico iuvenis dignissime sceptro, haec age pacata carmina fronte vide

quae tibi non aliquo qui fallat lumina fuco mittit Nicoleos Gallicus ille tuus.

Ille sub auspicio quae moerens carmina lusit haec prodire cupit qualiacunque tuo.

Sustulit indigno nuper mors funere patrem. Perdidit o quantum patria tota decus!

Quanta novem Aoniae fecerunt damna sorores!

Publica res quali concidit orba viro!

Ille beatorum sed vivit sede receptus et capit in CHRISTI gaudia vera sinu.

Sume libens animus quidquid tibi deditus offert: non data, mens dantis respicienda tibi.

Non aspernantur sincero corde ferentes supplice cum voto munera parva dei.

$\mathrm{Tu}$ quoque, terrarum atque hominum cui lata potestas peneque coelitibus par, imitare deos.

Invenies aliquid quod te quoque forte iuvabit.

Iudicio damnes quod minus ipse tuo.

Teque patremque tuum, clarissima nomina, scripsit, nomina carminibus non moritura suis, atque tuum voluit versu celebrare triumphum, tantus in obscuro ne premeretur honos."

\section{$\mathbf{1 6}$ sis Stroza scis $\mathbf{R} \mathbf{1 9}$ fallat Hessus fallant $\mathbf{R}$}

17 Haec ... 20 tuus: cf. Hessus, Sylv. 3.1.5-8: "Haec age, pacifico iuvenis dignissime sceptro, / haec age placata carmina fronte vide / quae tibi non aliquo qui fallat lumina fuco / mittimus."

21 Ille ... 22 tuo: from Strozzi, Erot. 1.1.65-66: "Ille sub auspicio primis quae luserat annis / haec prodire cupit qualiacunque tuo."

23 Sustulit ... 28 sinu: cf. Sabinus, Eleg. 3.4, f. F6r: "Sustulit indigno mors funere nuper Erasmum. / Perdidit o quantum Teutona terra decus! / [...] Heu mihi, quanta novem fecerunt damna sorores! / Publica res quali concidit orba viro! / Ille beatorum sed vivit sede receptus / et capit in Christi gaudia vera sinu."

29 Sume ... 37 scripsit: from Strozzi, Erot. 1.1.73-78, 83-85.

35 Invenies ... iuvabit: cf. Hessus, Sylv. 1.1.11: "Hic tamen invenies quod te quoque forte iuvabit."

39 atque ... 40 honos: cf. Hessus, Wirt., dedicatory letter, 1. 19-20: "Ipse novum volui versu celebrare triumphum, / tantus in obscuro ne premeretur honos." 


\section{ACClamatio in funere Henrici OCtavi, Angliae, Franciae et Hiberniae regis invictissimi, Nicolao Denisoto Gallo authore}

2a. Ergone fatali potuit Mors impia telo tam dirum patrare nefas? Patris inclyta proles, singultantem animam numerosque, EDUARDE, labantes dirige, nam tua res agitur. Tibi tristia mecum

Fata et ducentes fatalia pensa Sorores

incusare licet. Tecum fleat Anglia tota,

Francique Hibernique viri. Quae classica nuper

tantum, funereos iamiam tuba clangat in usus.

2b. [1] Illud idem video prope accidisse quod olim Polo histrioni contigit, ut non fictus neque simulatus luctus mihi agendus sit, sed verus plane ac certus dolor exprimendus. Nihil hic fucatum, nihil ad imitationem effictum. Ex vero, ex animo, ex re ipsa magnus mihi maeror incumbit. Magna me cruciat

5 miseratio, torquet iacturae magnitudo, vexat indignitas rei. Quibus omnibus

2a - 1 The idea of prefacing the eulogy with an eight-hexameter epigram comes from Voulté, Oratio, 213. But where Voulté takes most of his verses from Ercole Strozzi's epicedium for his father, Denisot takes his verses from Ercole Strozzi's epicedium for Duke Cesare Borgia. Voulté acknowledges the borrowing: "Ut suus honos unicuique iure merito tribuatur, versus quibus exorsus sum Stroza, vir sane suo tempore scribendo carmine felicissimus, fecit" (212). For Strozzi's verses, see Strozii poetae, f. 39v-40r. Ergone ... 2 nefas: cf. Arnollet, Bucolica 4.1-2: "Ergone praesenti potuit Mors improba mundo / tam saevum patrare nefas?"

2 Patris ... 8 usus: cf. Ercole Strozzi, Caesaris Borgiae Ducis epicedium, in Strozii poetae, f. 31r: "O Iovis inclyta proles, / tu rege singultantem animam numerosque labanteis. / Alcide, te flere decet. Tibi tristia mecum / Fata et ducentes fatalia pensa Sorores / incusare licet. [...] / Fer cristam eversam atque eversa insignia, Mavors, / moestaque funereos tantum tuba clangat in usus / et vos communem in medium conferte dolorem, / Hispani Oenotrique viri, pariterque fleamus."

4 nam tua res agitur: Hor. Ep. 1.18.84; reused in R, 5. Oceani Britannici plausus, 102.

2b-1 The eulogy lifts texts from Celio Calcagnini, Jean Voulté, and Georg Sabinus. In his hurry to put his fictional oration together, Denisot does not notice (or does not care) that two of the passages he takes from Voulté are imitations of passages that he takes from Calcagini. | Illud idem ... 5 indignitas rei: from Calcagnini, Oratio, f. 255r: "Idem video mihi prope accidisse quod olim Polo histrioni contigit, ut non fictus neque simulatus luctus mihi agendus sit hoc loco, sed verus plane ac certus dolor exprimendus. Nihil hic fucatum, nihil ad imitationem effictum, ex vero, ex animo, ex re ipsa magnus mihi moeror incumbit. Magna me cruciat miseratio, torquet iacturae magnitudo, vexat indignitas rei."

5 Quibus omnibus ... 9 debetis: from Voulté, Oratio, 213 (imitating Calcagnini, Oratio, f. 255 r, which Denisot goes on to use in paragraph 2): "Qua usqueadeo excrucior, ita conficior, ita de constantis animi gradu deiicior, ut me qui audiunt, etsi per se sint satis ad luc-

Humanistica Lovaniensia 67.1 (2018), 143-208 
usqueadeo excrucior, ita conficior, ita de constantis animi gradu deiicior, ut vos, viri spectatissimi, et si per vosmetipsos satis ad luctum exprimendum excitati estis, magis tamen de meo maerore angi quam ego susceptam deplorandi interitus provinciam perferre possim debetis.

[2] Hoc ideo maior mihi venia debetur si tanta pressus sollicitudine, si 10 tanto perculsus gemitu, minus assequi potero quod opto. Cum enim mihi venit in mentem quantum HENRICUS, ille regum rex invictissimus, virtutum omnium specimen clarissimum, quam ingenii bonitate, quo regiae maiestatis splendore, quo studiis studiosus favore, quantum linguis linguarum peritus tribueret, quam propensus esset omnibus bonis prodesse, tum denique excru- 15 cior, enecor, ac doloris magnitudini me imparem fateor. Ergo maiestas illa regia, illae omnes acerrimi ingenii amoenitates, omnes illi benignissimae naturae flores exaruere? Tot fecundissimi animi lumina dies unus, hora una, momentum unum abstulit?

[3] O Mortem! Ergo totius patriae praeclarissimum et praecipuum lumen 20 extinctum 〈est〉? O Fata! Ergo punctum temporis talem tantumque regem evertit? Dii immortales! Regem ergo vigilantissimum hic annus bonis omnibus fatalis ab oculis hominum eripuit? Dii, inquam, immortales, quae tam subiti occasus ratio? Cur illum nobis invidistis? DEUS BONE, cur insperata repentinaque morte illum ad te revocasti, qui pro communi omnium salute 25 semper vigilabat, qui omnibus aderat, consulteque, ne quid illius maiestas et reipublicae 〈dignitas〉 detrimenti acciperet, providebat, qui bonis omnibus ad virtutes et gloriam iter subministrabat?

tum exprimendum excitati, magis tamen de meo moerore angi debeant quam ego susceptam deplorandi interitus provinciam perficere possim."

10 Hoc ideo ... 19 abstulit: from Calcagnini, Oratio, f. 255r-v: "Quo maior mihi venia debetur si tanta pressus sollicitudine, si tanto perculsus gemitu, minus assequi potero quod opto. [...] Cum enim mihi venit in mentem quantum Hercules Stroza, ille inquam Hercules, omnium virtutum clarissimum specimen, [...] sua ipsius ingenii bonitate mihi faveret, quanto amore complecteretur, quam propensus esset omnibus bonis prodesse, tum demum excrucior, enecor, ac doloris magnitudini me imparem fateor. Ergo illae omnes acerrimi ingenii amoenitates, omnes illi benignissimae naturae flores exaruere? Tot [...] fecundissimi animi lumina dies unus, hora una, momentum unum abstulit? Dii immortales [...]!" Notice how Denisot in his haste mangles the paragraph's second sentence.

20 O Mortem ... 28 subministrabat: from Voulté, Oratio, 214 (imitating the passage in Calcagnini that Denisot has just finished quoting): "Quid? mortem? [...] Ergo totius Galliae praeclarissimum lumen extinctum est? [...] Ergo temporis punctum talem tantumque magistratum evertit? Ergo hominem vigilantissimum hic annus bonis omnibus fatalis ab oculis hominum eripuit? Dii immortales, quae tam subiti occasus ratio? Cur illum nobis invidistis [...]? Cur insperata repentinaque morte illum ad te revocasti qui pro communi omnium salute semper vigilabat, qui omnibus aderat consulteque ne quid reipublicae dignitas detrimenti acciperet providebat, qui bonis omnibus ad virtutes et gloriam iter subministrabat?" 
[4] In HENRICO sanctissimo atque integerrimo summa fuere omnia, non illa 30 quidem a parentibus et magistris tradita, sed divinitus concessa: incredibile ingenium, felicissima memoria, in administranda iusticia expedita providentia, vitiorum summus despectus, virtutum autem amplexus, maxima erga extraneos humanitas, optima in bonas artes voluntas, tanta in rebus omnibus constantia, tanta magnanimitas, tanta virtus, ut nullius unquam periculi

35 terroribus ab humanitate desciscere voluerit. Quid plura ad felicitatis cumulum desideratis? Multa me silentio pra<esterire cogit dolor quae in bello gerendo felicissime ac sapientissime perfecit. Quae si singula ante oculos 〈ponantur infinitaque alia ornamenta, quae nulla parte cessant, repetantur, mirifice hoc vulnus exulcerari video et recrudescere. Quis enim, obsecro, 40 regem illum cogitat et non frangitur? Nos navem quae naufragium fecit lugemus, castrum eversum deploramus, urbem victam et prostratam dolentissime ferimus, thesauros surreptos gravissime querimur, et non ad illustrissimi et prudentissimi regis occasum movebimur?

[5] Regem ergo divinitus meritum de patria omni dolorum genere quis

45 non statuat lugendum propter sapientiae admirationem ac virtutis illius, quae ita eminebant ut non solum in hoc imperio his laudibus eum excellere omnes intelligerent, sed etiam praestantissimis principibus Graecis et Romanis

29 In Henrico ... 43 movebimur: from Voulté, Oratio, 215: "In MiNUTIO sanctissimo atque integerrimo viro summa fuere omnia, non illa quidem a parentibus tradita, sed divinitus concessa: incredibile ingenium, felicissima memoria, in administranda iustitia expedita providentia, [...] vitiorum summus despectus, virtutum autem complexus, maxima erga prostratos atque afflictos humanitas, optima in bonas artes voluntas, tanta in rebus omnibus constantia, tanta magnanimitas, tanta virtus, ut nullius unquam periculi terroribus ab officio, nulla gratia ab humanitate desciscere voluerit. Quid plura ad felicitatis cumulum desideratis? Multa me silentio praeterire cogit dolor quae in Italia [...] felicissime ac sapientissime perfecit. Quae si singula ante oculos ponamus infinitaque alia ornamenta, quae undecunque sese offerunt, repetamus, vulnus tam grave et exulcerabitur et vehementissime recrudescet. Quis enim, obsecro, illum virum cogitat et non frangitur? Nos navem quae naufragium fecit lugemus, castrum eversum deploramus, urbem victam et prostratam dolentissime ferimus, thesauros subreptos gravissime querimur, et non ad illustrissimi et optimi viri occasum movebimur?"

44 Regem ergo ... 67 voluntates: from Sabinus, Poemata, f. T6v-T7v: "Non solum quia in ditione tua natus principem divinitus meritum de patria omni officii genere colendum mihi esse statuo, sed etiam propter admirationem sapientiae ac virtutis tuae, quae ita eminet ut non solum in hoc imperio his laudibus excellere te omnes intelligant, sed etiam praestantissimis principibus Graecis ac Romanis comparent. Nam et sapientiam tuam et animi magnitudinem declarasti statim initio cum, accepto principatu patrio, latrociniis ditionem purgasti summa cum virtute, qua in re, quod difficilimum est, et domesticas insidias consilio vicisti et saepe magnas coniuratorum copias parva manu acie dimicans ipse oppressisti. Postea ea moderatione ac iustitia in dicendo iure usus es, non solum ut neminem imperii tui poeniteret, sed ut, id quod res est, intelligerent te omnes divinitus his gentibus contigisse tanquam patriae patrem. Postquam enim tua diligentia ac iustitia pax provinciae constituta ac munita est, incredibile dictu, quam feliciter bonae res omnes in patria 
compararent. Nam et sapientiam illius et animi magnitudinem declaravit statim initio cum, accepta regali corona, latrociniis ditionem purgaret summa cum virtute, qua in re, quod difficilimum est, domesticas publi- 50 casque iniurias et saepe magnas coniuratorum copias gladio ultore oppressit. Ea etiam moderatione ac iusticia in dicendo iure usus est, non solum ut neminem imperii eius poeniteret, sed ut, id quod res est, intelligerent eum omnes divinitus his gentibus contigisse patriae patrem. Postquam autem illius diligentia ac iusticia tanto temporis spacio pax provinciae constituta 55 est, quam feliciter bonae res omnes in patria florere coeperunt, mores in civitatibus cultiores atque humaniores facti sunt, opes publicae privataeque creverunt, studia etiam literarum tum humanarum tum maxime divinarum excitata sunt! Denique nulla pars est reipublicae quam non singulari consilio ac virtute ornaret ac meliorem redderet. Quod ait Rex sapientissimus Cyrus, 60 nihil interesse inter patrem bonum ac bonum principem, nusquam alibi conspici clarius potuit quam in illius administratione, in qua cum vere patrio animo consilia illius omnia ad publicam utilitatem ac salutem suarum gentium referret. Vicissim ita omnes celsitudinem illius amabant ac venerabantur ut parentem. Nulli autem honores sunt veriores ac virtute digniores 65 aut praemia recte factorum gratiora prudentibus quam haec bonorum iudicia, studia, ac voluntates.

[6] Nonne ille nobis spes nostras, liberos, penates, opes denique omnes, omnibus eiectis hostibus sui nominis infensissimis, restituit? Alea ergo iacta est cum regis iactura, iactura, inquam, non ferenda, nullo tempore, nullo 70 saeculo reparanda. HENRICUS enim, ille totius quae usquam (est) maiestatis, nobilitatis, virtutis decus, interiit. Ille flos illibatus populi excidit. Eheu, quo

\section{6 iudicia Sabinus indicia $\mathbf{R}$}

florere coeperint, mores in civitatibus cultiores atque humaniores facti sunt, opes publicae privataeque creverunt, studia etiam cum literarum tum aliarum artium excitata sunt! [...] Denique nulla pars est reipublicae quam non singulari consilio ac virtute ornes ac meliorem reddas, ut, quod ait Rex sapientissimus Cyrus, nihil interesse inter patrem bonum ac bonum principem, nusquam alibi conspici clarius possit quam in tua administratione, in qua cum vere patrio animo consilia tua omnia ad publicam utilitatem ac salutem tuarum gentium referas. Vicissim ita boni omnes te amant ac venerantur ut parentem. Nulli autem sunt honores veriores ac virtute digniores aut praemia recte factorum gratiora prudentibus quam haec bonorum iudicia, studia, ac voluntates."

68 Nonne ... 74 officina: from Calcagnini, Oratio, f. 256r, 257r: "Nonne ille vobis, Quirites, spes vestras, liberos, penates, opes denique omneis, eiecto infensissimo nominis vestri inimico restituit? [...] Facta est enim suavissimi fratris iactura, iactura, inquam, non ferenda, nullo tempore, nullo saeculo reparanda. Hercules enim, ille totius quae usquam est amoenitatis, nobilitatis, virtutis decus, interiit. Ille flos illibatus populi excidit. Eheu, quo abiit illa animi acrimonia, illa vis, illud acumen ingenii, illa literarum officina?" 
abiit illa animi acrimonia, illa vis, illud acumen ingenii, illa virtutum omnium officina?

75 [7] Sunt et aliae illius laudes maiores ac principis propriae, quod ad tranquillitatem imperii suis rationibus suisque consiliis accommodaret. Cum autem et heroicae naturae praestantia et publica maiorum disciplina ad excellentem virtutem excitatus esset, illud magnae semper fuit prudentiae, quod nunquam studia literarum atque ingenuarum artium deponenda esse

80 maiestas illius duxit itaque in praestantissimis artibus omnibus ita versabatur ut cum doctissimis professoribus certare potuisset. Philosophiam ita tractabat ut ex scola et pulvere ad rempublicam transferret. Et quidem illi philosophiae deditus 〈erat) quae et praecipua est 〈et), ut veteres testantur historiae, digna regibus, quia 〈et〉 viros bonos efficit 〈et〉 ad gubernanda vitae 85 pericula consilium praebet. Versabatur in naturae inquisitione, in cognoscendis motibus siderum ac viribus. Huic doctrinae addebat iuris humani ac divini studium. Itaque saepe mihi venit in mentem illud quod Plato scripsit, respublicas beatas fore si aut philosophi imperent, aut illi qui imperant philosophentur. Regem ergo, principem nostrum, conferre poteramus, et 90 meritissimo iure, cum laudatissimis Graecorum ac Romanorum principibus.

[8] Credo, Mors saeva atque importuna, illud ipsum consulto advertisti ut maximo hoc commodo nostro obstreperes. Atqui neque hoc ipsum tibi omnino ex voto processit, quando tot eius etiam supersunt monimenta ut facile a tuis legibus atque oblivionis iniuria eius memoria vendicetur.

76 suis rationibus suisque consiliis] recte suas rationes suaque consilia (cf. textum Sabini) 88 imperent Sabinus imperant R

75 Sunt et ... 90 principibus: from Sabinus, Poemata, f. T8r-v: "Sed sunt aliae tuae laudes maiores ac principis propriae, quod ad tranquillitatem imperii tuas rationes tuaque consilia accommodas. Cum autem et heroicae naturae praestantia [...] et domestica maiorum disciplina ad excellentem virtutem excitatus esses, illud etiam magnae cuiusdam prudentiae fuit, quod nunquam studia literarum atque optimarum artium deponenda esse duxisti itaque in praestantissimis artibus omnibus ita versaris ut cum doctissimis professoribus certare possis. [...] Philosophiam ita tractas ut ex schola et pulvere ad rempublicam et ad vitae usum transferas [...]. Et quidem illi philosophiae te dedidisti quae et praecipua est et, ut veteres historiae testantur, digna regibus, quia et viros bonos efficit et ad gubernanda vitae pericula consilium praebet. Versaris enim in naturae inquisitione, in cognoscendis motibus siderum ac viribus. Huic doctrinae addis etiam iuris humani ac divini studium. Itaque saepe mihi venit in mentem illud quod Plato scripsit, respublicas beatas fore si aut philosophi imperent, aut illi qui imperant philosophentur. [...] Talem principem iure conferre possumus cum laudatissimis Graecorum ac Romanorum principibus."

91 Credo ... 94 vendicetur: from Calcagnini, Oratio, f. 257v: "Credo, Mors saeva atque importuna, illud ipsum consulto advertisti ut maximo ac pulcherrimo operi obstreperes [...]. Atqui neque hoc ipsum tibi omnino ex voto processit, quando tot eius etiam supersunt monimenta ut facile a tuis legibus atque oblivionis iniuria eius memoria vendicetur." 
[9] Sed iam plura non dicam, vereor enim ne mortuus, vel potius immor- 95 talis, factus, de vanis lachrymis et stultis querelis recte conqueratur, aequo animo paratoque mortuus. Quid mortuus? Imo vero melius et altius vitae initium adinvenit, laborum et miseriarum quiete fruitur. Cum igitur tot ornamenta in regno, populo, omnibus denique tam privatis quam publicis attulerit, quis illius mortem beatam non existimaverit? Quis, nisi insignis 100 impudentiae, de illius vita conqueretur? Quid illi commodius, quid opportunius contingere potuisset quam naturae ius acceptum restituere et haereditatem propriam cernere, a qua neque clam deturbari neque vi deiici potest? Non est ille lugendus, cuius vita laudabilis, mors honestissima fuit, cuius principium felix, cursus prosper, exitus beatissimus, una omnium voce 105 comprobatus est. Proinde animum colligamus et oculorum aciem in CHRISTUM convertamus, ut, qua nunc in aeterno illo immortalitatis regno fruitur, eam nos felicitatis partem tandem aliquando adipisci valeamus. DIXI.

\section{9 ornamenta in regno] recte ornamenta regno (cf. textum Vulteii)}

95 Sed iam ... 108 Dixi: from Voulté, Oratio, 217: "Sed iam plura non dicam, auditores, vereor enim ne mortuus, vel potius immortalis, factus, de vanis lachrymis et stultis querelis recte conqueratur, aequo animo paratoque mortuus. Quid mortuus? Imo vero melius et altius vitae initium adinvenit, laborum et miseriarum quiete fruitur. [...] Cum igitur [...] tot ornamenta regno nostro, $[\ldots]$ urbi, scholis, populo, omnibus denique tam privatis quam publicis attulerit, quis illius mortem non beatam existimabit? Quis, nisi insignis impudentiae, de illius vita conqueretur? Quid illi commodius, quid opportunius contingere potuisset quam naturae acceptum ius restituere et haereditatem propriam cernere, a qua neque clam deturbari neque vi deiici potest? Non est ille, non est lugendus, cuius vita laudabilis, mors honestissima fuit, cuius principium felix, cursus prosper, exitus beatissimus, una omnium voce comprobatus est. Proinde animum colligamus [...] et oculorum aciem in CHRISTUM convertamus oremusque ut, qua nunc in aeterno illo regno fruitur MINUTIUS, eam nos felicitatis partem tandem aliquando adipisci valeamus. DIXI." 


\section{Aegloga, quae Amaryllis dicitur,} super immatura morte Regis Henrici

$\begin{array}{lll}\text { AMYNTAS } & - \text { Henricus Rex } \\ \text { AMARYLLIS } & - \text { Anglia } \\ \text { IOLAS } & - \text { Eduardus Rex, Henrici filius } \\ \text { ARIADNA } & - \text { Ioanna, Eduardi mater }\end{array}$

\section{Nicolao Denisoto Gallo authore}

Quo feror, o superi? Nostri quae signa doloris sunt coryli testes: "Tua funera nuper, Amynta, vidimus. Ah, moriens morientem Amaryllida linquis."

Somnus ut extinctum rapuit Lethaeus Amyntam, ferrea nox omnes visa est descendere in agros et lupus et miles praedator ovilia lustrans debacchatur, agens effuso sanguine praedam. Non passim, velut ante, boves per tuta vagantur pascua. Clauduntur caulae, custode tenentur limina. Certantes lacerant mapalia venti.

Ecce sub obscuro turbatus flumine currit Temesus, increpitans saxa indignantia motu. Hunc iuxta quando licuit consuevit Amyntas pascere oves. Illi quoque cum pastoribus ipsis paruit omne nemus sylvaeque atque omnia prata. Illum omnis novit mundus, nam saepe superbos vicerat et fortes valido certamine victor. Illum omnes timuere ferae furesque dolosi. Illius ad vocem Poeni stupuere leones. E sylvis fugere lupi. Nec tempore nostro alter erat pastor sublimi maior Amynta.

O mecum, salices, mecum lugete, myricae! Lugeat hunc desertus ager desertus et hortus

3 - 1 For an earlier, but quite inaccurate, transcription of the poem, see Enea Balmas, "Un poeta francese in Inghilterra nel Cinquecento (con documenti inediti)", in M. Curreli, A. Martino (ed.), Critical Dimensions. English, German, and Comparative Literature Essays in Honour of Aurelio Zanco (Cuneo, 1978), 21-38, at 35-38. Balmas offers an introduction, at 21-34, but no commentary. | Quo feror, o: Lucan. Phars. 1.678; cf. R, 4. Epicedium, 209. | Nostri ... 3 linquis: cf. Pontano, Ecl. 2.1-4: "Hic cecinit Meliseus et haec quoque signa doloris / servat adhuc corylus: 'Vidi tua funera, coniunx / [...]'; caesoque in cortice signat / populus: "Ah moriens morientem, Ariadna, relinquis'."

4 Somnus ... 21 Amynta: Hessus, Idyl. 6.29-40, 45-46, 48-51.

22 O mecum ... 51 undis: Pontano, Ecl. 2.8, 36-37, 39-41, 118-137, 151-171.

Humanistica Lovaniensia 67.1 (2018), 143-208 
et deserta teges desertae et compita villae,

vos, vos, o segetes fraudataque praemia ruris,

et vanam sine fruge operam manuumque boumque,

et prata et sylvas ipsa et sine honore salicta.

Nonne repens lucem nox occupat, occidit et sol?

Crudeles radii, quo lux, quo purpureus sol

crudelisque dies? Mecum, o mecum ite, gementes,

ad luctum, mecum ite, deae, mecum ite, sorores

Temesides Dryadesque. Simul celerate, Napeae, et questus geminate et amarum spargite luctum.

Sol obiit, tenebrae exortae. Non pabula rorem, non imbrem sitiant segetes, non culta liquorem.

In lachrymas abeant rores imberque liquorque, unde fluant queruli lachrymoso margine rivi, murmuraque ipsa sonent: "Periit meus ignis Amyntas."

Lux abiit, tenebrae offusae. Iam robora frondes excutiant foliisque leves spolientur et alni.

Ipsa, comas, laurus tristesque, avellite, myrthi, ipsaque sint folia antiquo spoliata virore.

Arescat mihi ros, et apes sua dona negarint, torpescant flores, pomum mihi deneget arbos, horti flaccescant, et aquas mihi deneget amnis.

Triste ruat coelo excidium pecudi atque capellae, nec foetum dent armenta aut mulctralia succum.

Infelix coelo exitium ruat, ut neque lanam vellera dent, nullae veniant ad licia telae.

Stragem agris, stragem arboribus, terraeque ruinam

dent superi, et mediis tellus internatet undis:

tam dilectus erat, tam grex hunc omnis amavit.

Spargite odoratos, tumulo date, spargite flores, narcissos, violas, et odoriferos hyacinthos.

Balsama Coryciumque crocum myrrhamque comantem spargite et in viridi iuxta sic scribite fago:

Gloria sylvarum situs est hic, pastor Amyntas, quo non alter erat felicior omnibus oris.

Cetera fama tulit super et Garamantas et Indos.

57 Henrici Octavi Regis epitaphium in margine $\mathbf{R} \mathbf{5 8}$ alter corr. in margine pastor in textu $\mathbf{R} \mid$ oris Hessus horis $\mathbf{R}$

52 tam dilectus ... 58 oris: Hessus, Idyl. 6.58, 61-66.

59 Cetera ... Indos: cf. Verg. Aen. 6.794. 
Dignus erat qui Nestoreis frueretur Amyntas temporibus. Nunc hac tristi requiescit in urna. Nobis ille tamen moriens tria pignora liquit, spem generis, puerumque marem geminasque sorores.

Aspice quam referant patrios ad ovilia vultus!

Vivite et in patris, pueri, coalescite mores.

Tu nobis vive, o iuvenum pulcherrime Iola.

Nate patris summi, tu magni tuta parentis

pascua conduces. O misse faventibus astris, tecum nata salus nostris promittitur agris.

Indolis egregiae et virtutis certa futurae

signa in te, vultuque iubes spectare sereno

optima quaeque, etenim non haec sine numine divum

illa nitet facies, Phoebeae lampadis instar.

Claude oculos! Quis enim radios ferat ignipotentes?

Sed neque claude. Aperi potius! Da gaudia rebus.

Protinus effugient fures ab ovilibus omnes

raptoresque lupique truces et frigidus anguis.

Omnia securos praestabunt pabula foetus.

En famuli tibi Tritones simul aere canoro

servitium et volucres propter cava littora currus

promittunt, iter et placidum per caerula cursu

tercentum iuvenes, tercentum numina ponti, et tercentenis dant haec tibi munera gemmis

fulva auro, variata smaragdo et iaspide tecta.

Spargite humum, nymphae, preciosis floribus, in qua

presserit ille pedem, tenerae vestigia plantae.

Vos quoque, pastores, genialia tecta, periti, thure vaporifero circumlustrate quotannis

et carmen facite et laetantes dicite carmen:

"Salve, semidei proles insignis Amyntae,

nympharum genus, a magno velut aethere missum,

et nos et pecudes et rus defende paternum."

Felix, o felix felici pondere mater,

quae subiecta videns inter dumeta capellas

66 Eduardi Regis genethliacum in margine $\mathbf{R} \quad \mathbf{7 1}$ spectare $\mathbf{R}$ sperare Hessus

81 placidum R placido Pontanus

60 Dignus ... 78 foetus: from Hessus, Idyl. 6.81-106.

79 En famuli ... 84 tecta: Pontano, Ecl. 1, pompa tertia, 12-17.

85 Spargite ... 96 foetum: Hessus, Idyl. 6.107-118. 
altivagas errare a summi culmine montis

tam clarum viridi est enixa sub arbore foetum.

Ah dolor, ah desiderium! O Ariadna, quid istud dum paris ergo peris? Pariendo Ariadna necesse est ergo mori? Sed non moreris, quia vivit Iolas, spes quondam patris et patriae spes altera nostrae.

Interea tumulo extremum sic accipe carmen:

Musarum Musa et Charitum Charis, inclyta quondam

virgula nympharum, magni iacet uxor Amyntae, qua non nympha fuit praestantior omnibus oris.

Ingredere, o iuvenum pulcherrime! Iam omnia rident

et tibi detectum frondet nemus. Omnia pleno

fundit aperta sinu tellus. Tibi germinat omnis

arbor. Odoratos nunc primum lilia frondes

incipiunt habitare novo vernantia luxu.

Et gelidi fontes manant et rupibus altis

frigida milleno labuntur flumina lapsu

per virides ripas et amoena silentia. Postquam

te nostri accipiunt saltus, fugit omnibus omnis

graminibus serpens, fragrant suavissima tempe.

Aspice quam niteat toto formosior anno

Phoebus et insolito mundum ut splendore serenet!

Hoc erat, hoc ipsum nostrae quod saepe Camoenae optabant, etiam nemora omnia et ipsa petebant saxa salebrosas subter squallentia rupes.

Saepe meas pratis dum pasco virentibus agnas

quod canerem assiduo florentem carmine Iolam, quaerebant socii: "Dum spiritus hos reget artus, dum nemora et sylvae stabunt, dum flumina current,

102 Ioannae Eduardi matris epithaphium in margine $\mathbf{R} 105$ Eduardus rex salutatus in margine $\mathbf{R} \mathbf{1 0 8}$ frondes $\mathbf{R}$ montes Hessus

97 Ah dolor, ah desiderium: Pontano, Ecl. 2.205.

98 dum paris ergo peris: for this play on words, cf. Strozzi, Epigr., f. 84v: "mox parit, atque perit"; Voulté, Epigr. 163: "primum natum dum pario, pereo."

101 Interea ... carmen: cf. Sannazaro, Ecl. 1.101: "Interea tumulo supremum hoc accipe carmen."

102 Musarum ... 103 nympharum: cf. the epigram attributed to Denisot's beloved Valentina in Denisot 1550 (as in n. 4), f. c1r: "Musarum decima et Charitum quarta, inclyta regum / et soror et coniux [Verg. Aen. 1.47], Margaris illa iacet."

104 qua ... oris: a variation on 1.58 above.

105 Ingredere ... 133 capillos: from Hessus, Idyl. 8.17-58.

122 Dum spiritus hos reget artus: Verg. Aen. 4.336. 
ille meis, indocta licet, dicetur Iolas

carminibus Musisque meis dicetur Iolas.

Ipsa tuas laudes, ipsa haec armenta feraeque

auribus accipient stupidis. Dumque omnis ad auras

carmina nostra canet pastor, te montibus altis

aeriae rupes et concava saxa sonabunt."

Ingredere ergo tuas, iuvenum pulcherrime, terras!

Lecta corona tibi est quae castos aurea crines

contegat. En divae dicunt bona verba Camoenae:

"Vernantes in flore tegi patiare capillos."

Temesides Musae, vestri mihi fontis ab ortu in paulo maiora novas date carmina vires.

Et tu, magna patris soboles, EDUARDE, faveto.

Non indigna leges te carmina, ni mea forsan sordeat et nullum mereatur Musa favorem.

Non sordere putem inculto quia rustica vultu audeat ex ipsis prodire in moenia sylvis.

Audiit ipse suas cantantem saepe capellas Tityron et Latiam produxit Caesar in aulam, ipse tulitque suas Ptolomaeus dicere laudes, audiit et tenuem Siculi pastoris avenam.

Te quoque ne pudeat, Rex praestantissime, versu

cantari tenero, donec te serior aetas

praeclaris auctum meritis in carmina mittat heroa resonanda tuba. Nunc mollibus annis sic tibi, sic patriae decuit praeludere famae. Sic et acerba tui deflevimus ante parentis

funera et extinctum falso sub nomine Amyntam

lusimus et patria nobis te morte relictum spem generis gentisque tuae populique faventis.

Illa dies aderit qua te maiore Camoena inclyta gesta canam, neque enim tibi pauca supersunt facta gerenda, ipsos divum aequatura triumphos.

Tu modo, tu totis amplectere viribus istas virtutes quae te magnis heroibus aequent atque adeo nullam primis patiantur ab annis deperiisse tui partem nec laudis egenum

130 Eduardus 6. rex coronatus in margine $\mathbf{R} 134$ Digressio heroica in laudem Eduardi Regis in margine $\mathbf{R}$

134 Temesides ... 179 loquantur: from Hessus, Idyl. 13.1-118. 
esse sinant, verum supra convexa locabunt astra poli. Terrae tractus tua fama per omnes vivet inextinctumque manebit in omnia nomen saecula. Nam pereunt quaecunque potentia mundus gaudia dives habet. Semper manet inclyta virtus gestarumque insignis honos et gloria rerum, praecipue si facta suis illustria vates carminibus celebrent lucemque in versibus addant. Hi faciunt ut vivat opus quodcunque per orbem. Sic ferus Aeacides, sic aerumnosus Ulysses,

sic Thebae, sic Troia manent. Si rebus agendum exemplisque fuit, quo rustica Musa? Quid autem pastorum oblitus regem meditaris, Apollo?

Macte animo, iuvenis, virtutem imitare paternam! Sic mihi dignus eris quem Musa et Phoebus ab omni vindicet interitu atque locet tua nomina cedro.

Perge, age, perge, inquam, dignum te laude fateri. Invenies qui laude ferant super astra tuumque et genus illustrent et Martia facta loquentur.

FINIS

163 nomen Hessus tempus $\mathbf{R} \quad \mathbf{1 7 1}$ sic $\left.^{2}\right]$ sic Hessus si $\mathbf{R} \quad 172$ autem Hessus ante $\mathbf{R}$ 173 pastorum Hessus pastorem $\mathbf{R} \mathbf{1 7 9}$ loquentur $\mathbf{R}$ ut in textu Hessi (1539), recte loquantur 


\section{HenriCi OCTAVI, Angliae, Franciae et Hiberniae regis invictissimi, EPICEDIUM \\ Nicolao Denisoto Gallo authore}

4a. Iam satis est risum, risum est satis, Anglia. Plora!

En patet in gemitus area lata tuos.

Rex regum HENRICUS, quo non generosior alter, heu, pietas periit, si periisse potest.

Pieridum chorus omnis, ades, Charitumque, virentes ponite iam lauros. Non decet iste color.

Barbitos omnis eat, valeant cytharaeque lyraeque. Nunc lachrymae fiant quod fuit ante melos.

Quid causae? Cecidit fato percussus acerbo, qui vobis requiem temporibusque dabat.

Qui nisi qua talem decuit virtute fuisset, vester adhuc Gothica sorde iaceret honos.

Nunc vobis decus est et vita relicta per illum. Quidquid adhuc vitae est vos penes, ille dedit.

Et vos has omnes considere iussit in oras.

HENRICUS vivens gloria vestra fuit.

Illum, illum ecce premit duro nox ferrea somno, quo duce pax studiis floruit aucta suis.

Vos nemora et saltus, miseris ululate querelis. Nunc lachrymas habeat quaelibet herba suas.

Spargite inane viri corpus lustralibus undis, exangues liquido rore lavate genas.

Sed nec opus vobis deferre cadaver ad undas nec vitreas puri quaerere fontis aquas,

at potius riguos lachrymarum lumina fontes dent vestra. Ah, Musae, gloria vestra perit!

Flere libet quali doctum flevisse Biona carmine Trinacrius creditur ante senex.

4a-1 Iam satis est risum: cf. Petrarch, Ecl. 11.49: "Iam satis est fletum."

2 En patet ... tuos: cf. Ov. Her. 1.72.

3 quo non generosior alter: Ammonio, Carmina 2.190. For the wording, cf. Verg. Aen.

$6.164 ; 9.772$.

4 heu ... potest: cf. Ov. Trist. 1.4.28.

5 Pieridum ... 18 suis: Hessus, Epicedia 1.3-16, 35-36.

19 Vos ... 28 senex: Hessus, Epicedia 4.37-38, 27-34.

Humanistica Lovaniensia 67.1 (2018), 143-208 
In lachrymas abeant tristes Temesidos undae, sitque sua solito tristior amnis aqua.

Ut Phaetontiades luxerunt funera fratris, Phoebaeos audax cum male rexit equos, utque etiam extinctum mater ploravit Achillem, extemplo Illiaco diva profecta mari,

sic circum, moestae, deflete haec funera, nymphae.

Quid vos, quid, praeter flere, dolere, iuvat?

Talis eat gemitus, qualem Priamaeia coniux reddidit, ut $\mathrm{P}\langle\mathrm{h}\rangle$ thio victima facta duci.

Dicite ferales, mea carmina, dicite cantus.

Ah, nondum virtus debuit ista mori!

Carmine nec Maneis nec numina surda movemus quae nunc sub terris illius ossa tenent.

At potuit Manes, potuit fera monstra domare, cui tandem coniux reddita pulchra fuit.

Certa stat et nullis precibus mutata voluntas.

Arbitrio Fatum continet omne suo.

Heu tamen, immites, crudelia numina, Parcae, quantum erat huic avidas non habuisse manus!

Nam quid non habuit? Quid non fuit ille, quod ipsae fatales possent non meminisse deae?

Deneget iratus populo sua lumina Titan impiaque adversis moenia damnet equis.

Felix natorum, Niobe, post fata fuisti: eripuit sensum saxea forma tuum.

Felix, quae dominam, Cyane, dum deflet ademptam, Sicelidem subito fonte rigavit humum.

Felices etiam viridi quae tegmine clausae fletibus Heliades imposuere modum.

48 huic $\mathbf{R}$ hic Hessus

29 In lachrymas ... 36 iuvat: Hessus, Epicedia 3.127-136.

36 flere, dolere: Hessus, Eccles. 144; Epicedia 10.144 (reused in R, 4. Epicedium, 236); 11.48 .

37 Talis ... 38 duci: Quinziano Stoa, "Threnos", in Poematia aliquot, f. n8v.

39 Dicite ... 40 mori: refrain. The first line is based on the refrain in Hessus, Theoc. 1, f. A5v: "Dicite bucolicos, mea carmina, dicite cantus." The second line comes straight from Hessus, Epicedia 10.30.

41 Carmine ... 48 manus: Hessus, Epicedia 1.73-76, 79-82.

49 Nam ... 50 deae: Hessus, Epicedia 11.51-52.

51 Deneget ... 58 modum: Strozzi, Erot. 2.11.11-12, 33-36. 
Dicite ferales, mea carmina, dicite cantus.

Ah, nondum virtus debuit ista mori!

Iam subit humanae sortis meminisse, quod huius usqueadeo instabile est conditionis opus.

Nulli certus adest vitae modus. Omnibus horis fimus et occidimus, nascimur et morimur.

Heu dolor! Immitis quae tanta potentia fati!

Quam nulli placidas Mors habet atra manus!

Omnia demetitis. Quorsum audacia, Parcae, si ratio vobis aequior ulla foret?

Impietate, dolo, temere, et discrimine nullo vos iuvat humanum diripuisse genus.

Parcere vos decuit regi quem flemus adempto.

Utilis hic nobis quem violastis erat.

Dissimilis rerum facies et iniqua deum lex. Tempore quam constant optima quaeque brevi!

Tot superant pestes hominum vitaeque tyranni, quos melius vitam non habuisse fuit.

Dicite ferales, mea carmina, dicite cantus. $\mathrm{Ah}$, nondum virtus debuit ista mori!

O damnum nullo sortis reparabile casu, non, si, Croese, tuas pollicearis opes!

O labes nulla medici reparabilis arte, non, si Tymbraeus praebeat ipse manum!

O miseranda lues, quam vel facundus ab Orco Mercurius virga non revocare potest!

Hoc erat, ignotae quod edebant pectora curae, hoc erat, obscenae, quod cecinistis, aves.

Nunc saevos inter gemitus lachrymasque relinquor, Anglia, nec grata est vita futura mihi.

71 adempto Hessus adempti $\mathbf{R}$

59 Dicite ... 60 mori: refrain.

61 Iam ... 76 fuit: Hessus, Epicedia 2.109-112, 69-74, 77-82.

77 Dicite ... 78 mori: refrain.

79 O damnum ... 84 potest: mostly by Denisot. | damnum ... casu: cf. Andrelini, Bucolica 3.11: "damnum nullo reparabile casu." The same phrase occurs in Arnollet, Bucolica 4.46. $\mathbf{8 1}$ nulla ... reparabilis arte: Ov. Her. 5.103.

83 miseranda lues: Ammonio, Carmina 2.33: "miseranda lues invadit ovile."

$85 \mathrm{Hoc}$... 86 aves: Strozzi, Am. 1, opening distich of "Infelicem se in amore futurum [...] ait se admonitum", in Strozii poetae, f. 72v.

87 Nunc ... 88 mihi: Strozzi, Erot. 2.11.25-26.

Humanistica Lovaniensia 67.1 (2018), 143-208 
Ah, mihi iacturae tantum tantumque doloris conditio miserae mortis acerba tulit

ut semper miserae iustissima causa querelae crescat et aeternis commorer in lachrymis?

Heu saevae leges, heu dura potentia Fati, humanum sinitis quae nihil esse diu!

Non tantum Alcione quondam Ceyca peremptum, nec tantum Ismarium Daulias ales Ithym, tristia non adeo volucres ad busta volantes Memnonis in gelidis vallibus, Eure, tuis, quantum omnes huius lugent crudelia fata, fata per aeternos commemoranda dies.

Dicite ferales, mea carmina, dicite cantus.

Ah, nondum virtus debuit ista mori!

Neglexisse putem solidas vaga sidera leges illa quae facta est ultima luce tibi.

Illa sol latuit, latuit Saturnius hora, aurea confuso palluit ore Venus.

Protinus obscura tegitur caligine coelum, consurgit medio nox tenebrosa die.

Caerula terribiles permiscent aequora venti littoraque insanis fluctibus icta sonant.

Deucalionaeos demittit Iuppiter imbres. Nubibus abruptis fulgura crebra micant.

Hinc Notus, inde ruit Boreas. Hinc Eurus et illinc Affricus horrisono turbine bella gerunt corripiuntque rates et saevis fluctibus instant. Hic dextrum, at laevum mox latus inde ferit.

Hic furit in proram, puppim contrarius alter verberat, et vasto cuncta fragore fremunt.

Flumina fluminibus et fluctus fluctibus obstant. Non vento ventus, non aqua cedit aquae.

Hoc fuit, hoc urgens et inevitabile fatum, nec licuit fixum transiliisse diem.

89 Ah ... 94 diu: Strozzi, Erot. 6.10.29-34.

95 Non ... 99 fata: Hessus, Epicedia 4.104-105, 109-111.

100 fata ... dies: added by Denisot.

101 Dicite ... 102 mori: refrain.

103 Neglexisse ... 106 Venus: Hessus, Epicedia 2.89-92.

107 Protinus ... 120 aquae: Strozzi, Aeolost. 2.1, "Genethliacon", in Strozii poetae, f. 201r.

121 Hoc ... 122 diem: Hessus, Epicedia 2.31-32. 
Dicite ferales, mea carmina, dicite cantus.

$\mathrm{Ah}$, nondum virtus debuit ista mori!

Lanificae corpus videre exangue Sorores,

cum sic audita est de tribus una queri:

"Quis malus hic nostris obrepsit legibus error?

Cur non hic vires nos habuisse pudet?

Nos tamen invite fatalia stamina regi rupimus, heu, nostra non rep<ar>anda manu.

Quod nisi nostra loco non possent iura moveri, certum erat huic vitam restituisse semel."

Dixit et obducto siccabat lumina peplo, nec reliquae lachrymas continuere deae.

Dicite ferales, mea carmina, dicite cantus. Ah, nondum virtus debuit ista mori!

Sed quis tam iusto possit pugnare dolori? Quas dolor, heu, causas iste doloris habet!

Huius enim veras si pergam dicere laudes, divorum meritis dixero pene parem.

Exuit Alcides variis sua tempora monstris. Monstra vigil noster ne paterentur erat.

Num prohibere prior laus est quam tollere pestem?

Tutior est quisquis damna futura videt.

Vidit et ipse suo cavit prudenter honori, ne qua lues possit, ne quis obesse furor, atque ita consuluit patriae quantum esset 〈in〉 ipso, quantum etiam possent tempora dura pati.

Quantum afflicta huius fuerit respublica fato, flumina pene audent mutaque saxa loqui.

Publica curabat privato commoda censu, cuius pulchra etiam nunc monumenta manent.

129 invite $\mathbf{R}$ invitae Hessus $\mathbf{1 3 4}$ lachrymas Hessus lachrymis $\mathbf{R} \mathbf{1 4 2}$ paterentur $\mathbf{R}$ parerentur Hessus 151 censu Hessus sensu R

123 Dicite ... 124 mori: refrain.

125 Lanificae ... 134 deae: Hessus, Epicedia 4.63-72.

135 Dicite ... 136 mori: refrain.

137 Sed ... 138 habet: Hessus, Epicedia 6.95-96.

139 Huius ... 146 furor: Hessus, Epicedia 1.43-50.

147 atque ... 148 pati: Hessus, Epicedia 10.109-110.

149 Quantum ... 150 loqui: Hessus, Epicedia 6.107-108.

151 Publica ... 154 manu: Hessus, Epicedia 1.59-62. 
Nam quae cuncta patent ingentibus oppida muris, plurima munifica condidit ille manu.

Quid loquor ingenuas quo pectore foverit artes

et quibus has esset solus amare labor?

Nec tantum ingenuis summum decus artibus auxit, ingenii mira dexteritate fuit.

Omnia praescripta ratione mathemata novit, cognita nec Siculo plura fuisse seni.

Fortia ductilibus circundare moenia vallis atque aptis docuit ponere castra locis.

Instruxit peditum cuneos equitumque phalangas, pila, acies, turmas, cornua, signa, globos.

Illi si qua potest humanas ulla per artes gloria plena dari, gloria plena data est.

Omnia quae, superi, vos congessistis in unum, una simul fato perdidit hora nocens.

Dicite ferales, mea carmina, dicite cantus. Ah, nondum virtus debuit ista mori!

Dicite cum pardis, candentia lilia, quonam HENRICUS, qui vos tam bene rexit, abit?

Quo dilectus abit tuus, o ditissima rerum Anglia? Nonne perit pars quota viva tui?

Dic age, dic, plusquam orba, tuum cecidisse parentem, lumine quo casso mortua pene iaces.

Quantus erat, bone CHRISTE, tibi, meminisse iuvabit. Quantus et externis, o bone CHRISTE, fuit!

Omnes quotquot erant pietate accepit eadem, omnibus ex animo rex generosus erat.

Qualem divitibus, talem se gessit egenis. Unus erat candor, pectoris una fides.

153 cuncta $\mathbf{R}$ cincta Hessus

156 has Hessus his R 176 casso Hessus quasso R 182 unus Hessus vivus $\mathbf{R}$

155 Quid ... 156 labor: Hessus, Epicedia 1.67-68.

157 Nec ... 164 globos: Hessus, Epicedia 3.85-94.

165 Illi ... 166 est: Hessus, Epicedia 6.75-76.

167 Omnia ... 168 nocens: Hessus, Epicedia 3.97-98.

169 Dicite ... 170 mori: refrain.

171 Dicite ... 176 iaces: Hessus, Epicedia 3.51-52, (55-56), 63-64; 4.50.

177 Quantus ... 178 fuit: presumably by Denisot. | meminisse iuvabit: Verg. Aen. 1.203 (also used in R, 5. Oceani Britannici plausus, 105).

179 Omnes ... 188 fuit: Hessus, Epicedia 10.43-44, 49-58. 
Quod si iustitiam spectes, haec summa feratur laudis. Aristides Anglicus ille fuit.

Si quam res animo prudenti gesserit omnes, te, Iuli Caesar maxime, maior erat.

Quos adeo forti non sprevit pectore motus, non merito ut dicas, "Caesar et ille fuit".

Corporis egregias non hic describere laudes conor nec regni iura referre sui.

Eius enim totum clarissima fama per orbem floruit et celebri nomine notus erat.

Dicite ferales, mea carmina, dicite cantus. Ah, nondum virtus debuit ista mori!

Quod si iam libeat gentilia nomina nostris conferre, innumeri qui peterentur, erant.

Nostra alia est ratio, sancti quos unda lavacri abluit et fassi qui tua, CHRISTE, sumus, qui tua, CHRISTE, sumus fassi mortemque crucemque, vulnera, flagra, genus, munera, verba, fidem.

In quibus ille fuit tanto perculsus amore, quod fidei titulum coepit habere sacrae.

Quam bene pro solo vetera omnia nomina CHRISTO sprevit! CHRISTUS ei vitaque spesque fuit.

Quod si digna Deo virtus aequanda fuisset, rex hic ob hanc dignus ne moreretur erat.

Dicite ferales, mea carmina, dicite cantus. Ah, nondum virtus debuit ista mori!

Quo feror? Ah, nimium ratio huius inepta querelae! Gratari melius quam doluisse fuit.

Phoebe, mane. Non totus obit quem quaeris ademptum, parte etenim superest et meliore sui.

Dicite festivos, mea carmina, dicite cantus. Nil lachrymae prosunt, nulla querela iuvat.

205 aequanda $\mathbf{R}$ spectanda Hessus 206 hanc Hessus his $\mathbf{R}$

189 Corporis ... 190 sui: Strozzi, Erot. 4.21.9-10.

191 Eius ... 192 erat: Hessus, Epicedia 2.45-46.

193 Dicite ... 194 mori: refrain.

195 Quod ... 210 fuit: Hessus, Epicedia 10.61-70, 113-114, 123-124.

209 Quo feror? Ah: cf. R, 3. Aegloga, 1, with note.

211 Phoebe ... 212 sui: Hessus, Epicedia 1.95-96.

213 Dicite ... 214 iuvat: 1. 213 is a variation on the earlier refrain; 1. 214 is from Hessus, Epicedia 10.132. 
Perdidit HENRICUS falsae mala gaudia vitae.

Invenit vitae gaudia vera novae.

Exuit arma sui mortales corporis artus.

Induit arma animae non moritura suae.

Pone modum lachrymis, animosa Britannia, pone.

Nil, inquam, lachrymae, nulla querela iuvat.

Quin potius gratare, tui quod gloria regis inclyta, quod virtus non obitura manet.

Nec tu rege tuo orbatam te credere debes, qui nunc non minus est quam fuit ante tuus.

Creditur interiisse tibi. Nunc vivere primum incipit et vere muneris esse sui.

Quam bene conditio vitae est mutata prioris! $\mathrm{Si}$ quis ad hanc vere conferat, umbra fuit.

Non moritur quicunque sibi monimenta reliquit quique etiam laudes posteritatis habet.

Quanquam stulta hominum vanos sapientia motus fingat, non sapere est, sed mage desipere.

Nullus enim miseris modus est affectibus, et nos apparens falsi ludit imago mali,

tanquam vel nobis prosit vel lumine cassis incusare deos, flere, dolere, queri.

Cum nihil hinc ad nos redeat, nihil adferet illis praeter stultitiae non habuisse modum.

Ergo iucundos, mea carmina, dicite cantus.

Nil lachrymae prosunt, nulla querela iuvat.

Quare agite, o, vanas procul hinc auferte querelas quas fata HENRICI mortis acerba movent.

Ille quidem, taetro mortalis carcere liber carceris, aeterni possidet orbis opes.

Impia honoratum potuere extinguere corpus numina, non famae carmina viva suae.

215 Perdidit ... 222 manet: Hessus, Epicedia 10.127-134.

$223 \mathrm{Nec}$... 228 fuit: Hessus, Epicedia 7.13-14, 11-12, 9-10.

229 Non ... 230 habet: Hessus, Epicedia 3.157-158.

231 Quanquam ... 238 modum: Hessus, Epicedia 10.139-146.

239 Ergo ... 240 iuvat: cf. R, 4. Epicedium, 213-214, with note.

241 Quare ... 244 opes: Hessus, Epicedia 10.161-164.

245 Impia ... 252 dies: Quinziano Stoa, "Threnos", in Poematia aliquot, f. olv. 
Nam quacunque suis Aurora refulget ocellis quaque sub occiduas Cynthius intrat aquas

et qua tardus habet sua frigida plaustra Bootes atque ubi Lybs pluvio flamine cuncta premit,

HENRICI OCTAVI nomen venerabitur, immo semper et in cunctos gloria firma dies.

Est locus Aurorae primo surgentis in ortu. Empyrea in coelis dicitur ille plaga.

Ille vel Hesperidum cultis certaverit hortis. Alcinoi varium vicerit ille nemus.

Hic facili vernant aeterna rosaria cultu. Luxuriat vivo germine dives humus.

Aurea felicem pingunt violaria campum.

Scilicet hic sedes imperiosa Dei.

Illic felices inter nunc pascitur umbras, HENRICUS vivit nectare et ambrosia, non quali pavisse deos pater ipse deorum fertur ad ardentem Iuppiter Oceanum, sed qualem coeleste animae genus esse feruntur, qua sua per CHRISTUM pascit adulta fides.

Felices animae, quibus obtigit ista voluptas, felices, quibus haec vita beata datur!

Ergo felicem tete bene dixero, nempe quam bene mutata nunc loca sorte tenes,

unde haec vana hominum rides suspiria et istas undantes lachrymis respuis inferias.

Nos tamen haec dedimus memori conscripta libello carmina, moerenti qualiacunque stilo, non quia vel Maneis his credam posse movere nostra vel aethereas tangere verba domos, sed quia non potuit vivum celebrare quod ardens voverat, extinctum nostra Thalia gemit.

FINIS

$\mathbf{2 7 5}$ movere $\mathbf{R}$ moveri Hessus

253 Est ... 270 tenes: Hessus, Epicedia 6.35-54.

271 unde ... 277 potuit: Hessus, Epicedia 10.165-171.

277 quia ... celebrare: cf. Voulté, Oratio, 212, liminary epigram, 1. 1: "Quod te non potui vivum celebrare, Minuti." | quod ... 278 gemit: presumably by Denisot. 


\section{4b. De eodem}

Henrico extincto, cecidit Mars, bellica Pallas, pene etiam mundus quidquid honoris habet.

\section{4c. De eodem}

"Ipsa me ut a regno rapuerunt fata, repente regnum aliud maius fata dedere mihi."

\section{OCEANI BRITANNICI PLAUSUS super ingressu EdUARDI VI, Angliae, Franciae et Hiberniae regis invictissimi, Nicolao Denisoto authore}

Audiit Oceanus pater ille Britannicus illum advenisse diem quo, formosissima, tandem, Anglia, demissum coelo et virtutibus auctum acciperes iuvenem et regem qualem ipsa petebas. Ergo pater medio nymphis permixtus in antro tunc iacuit cubito innixus. Cui candida Nais, docta lyrae digitis percurrere fila, canebat carmen, quod totidem numeris Niseque Spioque reddebant. Sol hibernos circumvagus orbes axe terens medio currum librabat Olympo.

Ille avidis allata pater postquam auribus hausit promissosque olim fatis sibi laetus honores

4b - 1 Henrico ... 2 habet: cf. Giraldi, Poematia, 159: "Alfonso extincto Mors secum laeta, 'Quid,' inquit, / 'hoc potuit maius sternere dextra mea? / Hoc caeso, cecidit Mavors, hoc bellica Pallas, / hoc decoris toto quicquid in orbe fuit'."

4c-1 Ipsa ... 2 mihi: cf. Jean Voulté, epitaph for the Dauphin François (1518-1536), first published in Recueil de vers Latins et vulgaires de plusieurs poëtes Francoys composés sur le trespas de feu Monsieur le Daulphin (Lyon, 1536) [USTC 37948], f. A4v; reprinted in Voulté, Epigr., 190: "A regno, patre rege, trahunt dum fata, repente / regnum aliud, regem dant quoque fata patrem."

5-1 Audiit ... illum: added by Denisot.

2 advenisse ... 100 Regi: the verses copy out or adapt selected passages from Pietro Bembo's Benacus, a panegyric of Bishop Giovan Matteo Giberti (1495-1543), first published in 1524 and frequently reprinted thereafter. Denisot probably read the poem in Poematia aliquot, f. b3r-b6v. For a text and translation (but omitting five verses after 1. 163, used by Denisot at 1. 79-83), see M.P. Chatfield (ed., tr.), Pietro Bembo, Lyric Poetry. Etna (Cambridge, MA, 2005), 66-81. In Bembo's poem, the god of Lake Garda summons the region's rivers to his grotto to help him celebrate Giberti's accession to the see of Verona. In Denisot's version, the British Ocean summons England's rivers to help him celebrate the accession of Edward VI to the throne. 
agnovit, tangens haerentem uligine barbam

demulcensque manu, iussit vicina vocari

flumina. Conveniunt nitidis Sebernus in undis

piscosusque altas involvens Umber arenas

et pulcher cursu fecundans Trentius arva, deductus rivis, et cultos Skelea campos, tum rapidus fluvioque Nidus spectandus amoeno, Warsaeus Marsusque potens et Caldra Ierymisque insignisque Vore, Enaeus, Rydaleque, deisque.

Quos tunc atque alios velatus arundine crinem excipit Oceanus venientes limine primo obvius atque omnes in saxea tecta recludit, laetifico cordis non celans gaudia vultu.

Qui simul ac udos posuere sedilibus artus cristallo rigida fultis et iaspide glauca, continuo nymphae mensas ante ora deorum speluncae in medio niveis mantilibus alte consternunt dapibusque onerant Dictaeaque plena vina ferunt referuntque manu calicesque madentes praecingunt myrto atque implexis flore coronis.

Post ubi prima quies epulis, deus ipse magister undisoni domitorque maris, praesentia circum numina respiciens, his vocibus ora resolvit:

"Quod votis toties nequicquam optavimus omnes nobiscum divi, fausto nunc sidere luces, volventes luces fatorum orbisque ministrae, advexere. Vehit pleno Bona Copia cornu largaque pomifera praetendit munera dextra. Flos etenim iuvenum - mira virtute parentem augendo in regno, pietate, fideque sequetur, agmina tot bellique faces, quas vidimus ipsi, suppeditabit - erit victor, Iove missus ab ipso. Plaudite, Tritones, EDUARDO plaudite Regi.

Ecce illi Pallas, proles Iovis, ut bona mater, ut mater bona quae caro timet omnia nato, in duros optat comitem sese addere casus, et pueri mirata oculos et verba loquentis, 'Ipse meas artes, iam nunc tibi', dixit, 'habeto.'

Plaudite, Naiades, EDUARDO plaudite Regi.

15 Fluvii maiores Britannici in margine $\mathbf{R}$ 
Anglia, plaude! Tui magnum genus aspice regis. Iam non curarum, non commemorare laborum una potes? Tolle egregium per saecula nomen, tolle decus, daque alta virum volitare per ora.

Plaudite, Tritones, EDUARDO plaudite Regi.

Hoc scio quod miseris viduatas civibus urbes accipiet vacuosque suis cultoribus agros replebit numerum exaequans augensque priorem oppidaque ingenti multum quassata ruina restituet pulchroque dabit splendescere vultu. Plaudite, Naiades, EDUARDO plaudite Regi.

Quantum Trinacriae vertex se sustulit Aethnae aut cinctus stellis Atlas aut Caucasus ingens, tantum tanta novo tollat sese Anglia rege, rex etenim novus hic vivens praesentia saecla firmabit veterumque abolebit damna malorum. Plaudite, Tritones, EDUARDO plaudite Regi.

Ecce illi laeto vestit se gramine tellus, illi sylva comas nutrit, huic pabula surgunt, et spisso quem rete trahat vel arundine longa flexivagus nostris hinc crescit piscis in undis. Plaudite, Naiades, EDUARDO plaudite Regi.

Ecce illi summo Parnassi e colle sorores dona ferunt, sacram lauri de fronde coronam et plectrum et cytharam scriptasque ab Apolline chartas, aeternum quas ediscant celebrentque minores. Plaudite, Tritones, EDUARDO plaudite Regi.

Ut Phoebo atque Iovi confectis Graecia lustris sacra olim et pleno posuit certamina campo, sacra illi ludosque illi sic Anglia tellus instituat, sic illa eius de nomine dicat. Plaudite, Naiades, EDUARDO plaudite Regi. Ut cum lethiferos accendit Syrius ignes, rivus aquas, hortus flores, pratum abnegat herbas, ipsa suos sitiens foetus non educat arbos, intereunt fruges siliqua labente perustae, arva colit nemo siccis arentia glebis, vomeris et durum non admittentia dentem, cuncta iacent nimio coeli contusa calore: 
tristia sic istis aderant prius omnia terris

HENRICI nuper crudeli in funere Regis.

Plaudite, Tritones, EDUARDO plaudite Regi.

At postquam laetos effundit Iuppiter imbres,

rivus aquas, hortus flores, pratum explicat herbas,

ipsa viret tellus, ripae, collesque supremae,

frondescit nemus omne et gratas sufficit umbras,

cuncta vigent coeli fecundis roribus arva:

sic iucunda novo sunt omnia et omnia rege.

Plaudite, Naiades, EDUARDO plaudite Regi.

Sit satis haec dixisse mihi. Tu, Temesus, illum

alloquere. Haec tua res agitur. Quid ego audio? Iam plebs

tota fremit plausu atque hunc bellica tota salutat machina. Magnorum quae sit sententia divum, dic, age. Forsan et haec olim dixisse iuvabit."

\section{FINIS}

\section{Temesus. EduARdus SeXtus ReX Salutatus Nicolao Denisoto Gallo authore}

Caeruleis generosus aquis Rex Temesus antro, sulphureo rapidos igne movente globos, unde resultabat coelum ceu fulmine misso cum venit aethereo magnus ab axe fragor, praeterea Oceani divinum et amabile carmen

Tritonum plausus Naiadumque choros, audieratque ut vulgus "Io, bona verba!" sonaret per loca, per cunctas voce sonante vias,

102 tua res agitur: cf. R, 2a. Acclamatio, 4 (from Hor. Ep. 1.18.84).

103 tota fremit: Ov. Met. 6.146 (also used in R, 6. Temesus, 116). | bellica ... 104 machina: cf. Sabinus, Eleg. 1.2, f. A5r: "Intonat ex altis et machina bellica muris." 105 Forsan ... iuvabit: cf. Verg. Aen. 1.203 (also used in R, 4. Epicedium, 177).

6-1 Caeruleis ... antro: cf. Pontano, Eridanus 1.1.1: "Caeruleis generose vadis, rex divitis agri."

2 sulphureo ... globos: cf. Sabinus, Eleg. 1.2, f. A5r: "Sulfureo rapidos quae iacit igne globos."

3 unde ... 4 fragor: Sabinus, Eleg. 1.7, f. C5v.

5 praeterea ... 6 choros: presumably by Denisot. | amabile carmen: Hor. Ep. 1.3.24.

6 Naiadumque choros: Ov. Fast. 1.512.

7 audieratque ... 8 vias: cf. Sabinus, Eleg. 1.7, f. C5v: “Vulgus ‘Io Paean' omnesque ‘Triumphe' canebant, / per loca, per cunctas voce sonante vias." 
humida Naiadum perterritus antra sororum

liquit et e mediis sustulit ora vadis.

Alga virens barbam, crines uligo tegebat.

Densus in undoso corpore muscus erat.

Ut nova conspexit plaudentis gaudia turbae, regis et agnovit signa relata sui,

intorquens madido rorantia lumina vultu,

fatidico tales edidit ore sonos:

"Londinae turres, patrii, salvete, Penates, urbs faustis, salve, condita temporibus!

$\mathrm{O}$ nimium felix tellus nimiumque beata, tu modo coelicolas relligiosa cole.

HENRICI, salve, ingenua armipotentis origo et decus et patriae spes, EDUARDE, tuae.

Hanc tibi iam lucem nitido produxit ab axe per coelum volucres qui moderatur equos.

Aspice quam celebri concurrant undique pompa, quam solium stipent millia multa tuum!

Exaudita diu populorum vota precesque tandem te nobis hac tribuere die

qua rerum ingenti perfecta mole quievit, quam festam iussit maximus esse Deus.

Haec Domini lux est Dominoque dicata tibique conveniens, regni qui caput huius eris.

Hac fecunda die pubescunt gramina campis. Floriferos aperit terra benigna sinus.

Ipsa quoque auspiciis adsunt felicibus astra, atque parant faciles prospera fata vias.

\section{9 mole Stroza molle $\mathbf{R}$}

9 humida ... 22 tuae: cf. Sabinus, Eleg. 1.7, f. C5v-C6r: "Humida nympharum perterritus atria Suevus / clausit et e mediis sustulit ora vadis. / Alga virens barbam, crines uligo tegebat, / densus in undoso corpore muscus erat. / Ut nova conspexit sed ovantis gaudia turbae / et ducis agnovit signa relata sui, / intorquens madido rorantia lumina vultu, / fatidico tales edidit ore sonos: / 'Salve, magnanimum genus armipotentis Achillis, / o decus, o patriae spes, Ioachime, tuae'."

23 Hanc ... 24 equos: Melchior Acontius, in Sabinus, Poemata, f. Q4v.

25 Aspice ... 26 tuum: Hessus, Sylv. 1.1.47-48.

27 Exaudita ... 32 eris: Strozzi, Aeolost. 2.1, "Genethliacon”, f. 200r.

33 Hac ... 34 sinus: Strozzi, Erot. 4.5.11-12.

35 Ipsa ... 46 tui: Strozzi, Aeolost. 2.1, "Genethliacon”, f. 200v-201r. 
Te veniente gravis Saturni stella maligni occidit, assuetam deseruitque domum, totaque disposito coeuntia sidera coelo promittunt sceptris omnia laeta tuis.

Iustitia ecce, suis comitata sororibus, illinc observat gestus, Attica diva, tuos.

Ad caput ecce tuum assistit tibi regia Iuno, et Fortuna tuos excubat ante pedes.

Macte animo et virtute, deum certissima cura, spes et amor populi deliciaeque tui!

Non tantum Delos gaudebat Apollinis ortu, nec tantum nato Gnosia terra Iove, quantum laeta tuo se tota Britannia vultu. Non tegit affectus officiosa suos.

Non tuba, non cytharae, non tibia, non cava cessant tympana, non agili cymbala pulsa manu.

Tecta viaeque procul resonant, delubraque passim festivis augent gaudia tanta sonis.

Quid potuit laetae contingere gratius urbi? Quidve tuo maius numine terra dare?

Digne cani, iuvenis, centum per carmina linguis, non debes meriti laude carere tui,

ne tua praeclaris tot dotibus aucta iuventus virtutis possit non meminisse suae.

Quod tibi ne timeas, Rex o generose, futurum, plurima sunt quae 〈te〉 commonuisse queunt.

Fulget imaginibus primum domus inclyta, quae te eduxit regem nobilitate sacrum.

Claraque maiorum si contemplabere facta, illustres tanta laude stupebis avos, totque duces inter, clarissima nomina, tantum volve animo fuerit gloria quanta patris, innumerabilibus quo non fuit alter ab annis principe consiliis iustitiaque prior.

Magnanimi quem non HENRICI nomen in orbem, quo non fama abiit quove sub axe latet?

47 Non ... 54 sonis: Strozzi, Aeolost. 2.1, "Genethliacon”, f. 202r.

55 Quid ... 56 dare: Strozzi, Erot. 5.1.7-8.

57 Digne ... 108 eris: Hessus, Sylv. 3.1.27-48, 59-96.

Humanistica Lovaniensia 67.1 (2018), 143-208 
Quo tamen hunc, qui te talem dedit, ore canemus?

Non facit ad laudes, quanta sit, ulla chelis.

Divinum ingenium divinaque plectra meretur,

qui potuit tantum te genuisse decus.

Et quamvis nulli regum virtute secundus cesserit, hoc meritum nomine maius habet,

divinum in terris animum te nanque gerentem cum daret, orbi et opes divitiasque dedit.

Cuius ut eximiae flos indolis omnia spondet, maxima sic debet non sine teste coli.

Sed neque te merita cariturum laude timebis, et nec in obscuro fama futura tua est.

In tua certatim surgent praeconia, quorum

Musica divinum pectora numen habent.

Macte animo! Veteres duce te revocabimus annos, queis sacra Musarum gloria vivet adhuc.

Purior Aonidum per te fluet unda sororum et suus ingeniis restituetur honos.

Tu modo sume animum dignum te principe, teque huius opus rarum temporis esse puta.

Hoc facies, si te non ad mediocria natum, maxima sed partes noveris esse tuas.

Sollicitent alios tituli sine rebus inanes ociaque in magnis non habitura locum.

Divitiis inhient illi et popularibus auris, hos iuvet assiduis luxibus esse graves.

$\mathrm{Tu}$, qui vere tuo tam flore〈s〉 indole, iamiam virtutem extendas per benefacta tuam,

et tibi praesentis sordescant nomina famae curaque venturae maxima laudis eat.

Ibis ab exemplis per splendida facta tuorum. Gloria sic regni tanget ad astra tui!

Te patris atque patrum regnum manet. Unus obibis qua vice par ipsis regibus esse queas.

Quare age virtutem regnis adiunge paternam. Magnus ut es, magnos maximus inter eris.

Vade etiam quo fata iubent superisque vocatis. Auspicium imperii nobile sume tui.

109 Vade ... 110 tui: cf. Melchior Acontius, in Sabinus, Poemata, f. Q5r: "Ite igitur quo sacra iubent superisque vocatis, / auspicium fausti sumite coniugii." 
Quae tibi nunc parent praesenti numine gentes, respicere, atque ut fas, semper amare velis.

Nil proprium conferre valent, nam spiritus et res et quidquid possunt, iuris id omne tui est.

Concurrunt, spectant, mirantur singula, summis laudibus ad coelum patria tota fremit,

incomperta mihi quorum nec nomina constant, nec datur hoc spacium posse referre loco.

Innumeri iuvenes misto clangore tubarum en quassant agili tympana pulsa manu.

Intonat ex altis et machina bellica muris, sulphureo rapidos quae iacit igne globos.

Compita spectantis populi stant plena viarum, augustumque frequens turba coarctat iter,

atque coit regni cum nobilitate senatus.

Omnis in occursum vivida turba ruit,

haud secus ac victis cum dicitur hostibus olim excepisse suos obvia Roma duces.

Digne, inquam, iuvenis centum per carmina linguis, non debes meriti laude carere tui.

Vive ergo, Rex, vive, animo dignissime tali, indolis et noli non memor esse tuae.

In te vera fides pietasque paterna, sit omni labe carens animus nec simulatus amor.

Nil nisi magnanimo mediteris principe dignum, nil nisi quod deceat quodque probetur age,

et tibi dilectos, quibus es gratissimus ipse, aequa rex cives optime lance regas.

111 Quae ... 112 velis: Strozzi, Aeolost. 1.7, “Ad divum Herculem”, f. 199v.

113 Nil ... 114 est: Strozzi, Aeolost. 2.1, "Genethliacon", f. 202v.

115 Concurrunt ... 116 fremit: presumably by Denisot.

116 patria tota fremit: cf. Ov. Met. 6.146 (also used in R, 5. Oceani Britannici plausus, 103).

117 incomperta ... 124 iter: the passage quotes and adapts scattered lines in Sabinus, Eleg. 1.2, f. A5r-A5v. At 1. 121, Denisot uses the same verse as in R, 5. Oceani Britannici plausus, 103-104; at 1. 122, he repeats the same verse as at 1.2 above, but now in proper context: "Sulfureo rapidos quae iacit igne globos."

125 atque ... 128 duces: Sabinus, Eleg. 1.2, f. A3v.

129 Digne ... 132 tuae: Hessus, Sylv. 3.1.27-28, 105-106.

133 In ... 134 amor: Strozzi, Aeolost. 1.1, "Ad divum Herculem”, f. 189r.

135 Nil ... 136 age: Strozzi, Aeolost. 1.7, "Ad divum Herculem”, f. 199v.

137 et tibi ... 142 fides: Strozzi, Aeolost. 1.1, “Ad divum Herculem”, f. 189r. 
Nec sine quod tumido comitata potentia fastu sit damnosa bonis iustitiamque premat

nec digno sine honore tuos opibusque relinquas, quorum stat longo tempore nata fides.

Utque animo flores et corpore, floris honorem maxima ne turbet quaelibet aura cave.

Sit tibi cura etiam rabiosas tollere lites, quae gravibus causam saepe dedere malis.

Serus et invitus sontes velutique coactus puniri vultu commiserante iube,

et tua saepe tuum moveat clementia plebem, quandoque offensas dedidicisse iuvet.

Et quos longa fides et amor tibi iunxerit, illis tandem pro meritis praemia digna feras.

Scilicet hoc etiam meditare, ut premia reddant pro meritis reges gentibus esse datos

ac mentes hominum officiis et amore ligari formarique bonis artibus imperia

deque opibus tantis post ultima fata relinqui nil praeter laudes et benefacta tibi.

Sic tua, nec dubita, seros durabit in annos extremo virtus non obitura die.

Vive diu felix, patriae pater, et tibi sospes vivat consilii provida cura tui."

143 Utque ... 144 cave: Hessus, Luth. 4.25-26.

145 Sit ... 150 iuvet: Strozzi, Aeolost. 1.1, “Ad divum Herculem”, f. 189r.

151 Et ... 152 feras: Strozzi, Aeolost. 1.7, “Ad divum Herculem”, f. 199v.

153 Scilicet ... 158 tibi: Strozzi, Aeolost. 1.1, “Ad divum Herculem”, f. 193r.

159 Sic ... 160 die: Hessus, Sylv. 3.1.107-108.

161 Vive ... sospes: Strozzi, Aeolost. 1.7, “Ad divum Herculem”, f. 199v.

162 vivat ... tui: presumably by Denisot. | provida cura: Ov. Fast. 2.60. 


\title{
B. Hecatodistichon (1550)
}

The source for this partial edition is a digital facsimile of the Hecatodistichon (1550), available online at Gallica. Another facsimile is available via Google Books. The 104 distichs, as printed in the editio princeps, have been independently edited and translated three times thus far. ${ }^{42}$ The poem's first twelve distichs have been anthologized and translated by Stevenson and Davidson..$^{43}$ All of these texts and translations, however, are marred by serious errors. ${ }^{44}$

In keeping with the focus of this study, the notes aim only to identify Denisot's Neo-Latin sources, not to elucidate his texts or discuss precisely how the borrowed texts are adapted. ${ }^{45}$

\author{
Annae, Margaritae, IANae, \\ SORORUM VIRGINUM, HEROIDUM ANGLARUM, \\ in mortem Divae MARGARITAE VALESIAE, Navarrorum reginae,
}

\section{Hecatodistichon}

\section{Accessit \\ Petri Mirarii ad easdem virgines epistola, una cum doctorum aliquot virorum carminibus.}

1. Illustrissimis Principibus, Annae, Margaritae, Ianae Semorianis sororibus, Nicolaus Denisotus Cenomanus salutem dicit.

[1] Nescio quo pacto fit, illustrissimae heroinae, ut non minor amor sit apud homines avorum in nepotes quam parentum ipsorum erga filios. [2] Id nunc

5 per me doctus ita esse re ipsa comperi. [3] Quum enim audissem et vos Navarrensis reginae recentem obitum non solum lachrymis sed etiam

42 Hosington 1996 (as in n. 9); P. Demers, "The Seymour Sisters. Elegizing Female Attachment", Sixteenth Century Journal 30.2 (1999), 343-365 (without knowledge of Hosington); and D.F. Sutton, online edition posted in 2002 (last modified in 2003) in The Philological Museum, at www.philological.bham.ac.uk/seymours (without knowledge of Hosington and Demers).

43 J. Stevenson, P. Davidson (ed., tr.), Early Modern Women Poets (1520-1700). An Anthology (Oxford, 2001), 39-42.

${ }^{44}$ For the distichs as revised in Denisot 1551 (as in n. 6), see H. Chamard (ed.), Joachim du Bellay, Oeuvres poétiques, vol. 4 (Paris, 1983), 57-84.

${ }^{45}$ For biblical/liturgical sources, see Hosington 1996 (as in n. 9), 148-152. For a literary appreciation, see Jugé 1907 (as in n. 1), 59-63; Hosington 1996 (as in n. 9), 152163; Demers 1999 (as in n. 42), 352-354; Speziari 2016 (as in n. 1), 187-192. 
centum alternis distichis prosecutas esse, nihil mihi prius fuit quam ut illos versus primum crebris literis flagitarem, deinde acceptos charissimorum nepotulorum loco haberem. [4] Sic enim eos proprio iure vendico ut meos appellem, qui vos tales istic quum essem vestrosque generosissimos animos 10 tanquam parens alter in poeticis nostrisque patriis literis (quum alioqui Ioannes Crannus praeceptor vester, utriusque linguae scientissimus, abunde caetera pro sua doctrina diligentiaque praestaret) pro mea parte et formaverim et educarim, nunc a vobis prognatos versiculos quasi alteram ingenioli nostri propaginem agnosco atque amplector, non minus mihi quam 15 vobis et ornamento futurum et voluptati. [5] Itaque statim ut legi non potui abstinere quin eos, si non pro meis, at certe tanquam mihi vobiscum communes liberos, in vulgus edendos curarem, nimirum existimans neque vestro discipularum splendore neque mea vestri quantulicunque praeceptoris opera indignos in manus hominum perventuros, quippe qui sint ita scripti ut 20 et in nobilissimam reginam a nobilissimis regis consobrinis et in piissimam ac doctissimam principem a piissimis doctissimisque principibus puellis luculentius atque suavius scribi non potuerint. [6] Sic enim, quam vivam singulari quodam studio amandam et imitandam vobis duxeratis, eius mortuae veram effigiem illis versibus exprimitis ut et illam a morte vivam 25 probetis et in vita mortuam etiam atque etiam fuisse ostendatis. [7] Amant igitur vestros versus qui illam non oderunt; vestros versus non oderunt qui illam amant, sicut amant profecto et apud suos et apud externos, vestrates praesertim, plurimi, cum doctrina eius incredibili tum pietate prope singulari commoti. [8] Nec dubito quin, quod plerunque fit, parcente mortuis invidia, 30 crescat magis ac magis in dies mortuae reginae memoria, crescente autem illa, crescent et vestri versus nomenque. [9] Crescentibus porro vestris versibus ac nomine, ne meum quidem (qui in partem docendi vos tales tantasque aliquando venerim) iacebit inobscurum. [10] Valete, ter geminae sororculae Principes, vestrique Denisoti erga vos studium boni consulite. [11] Datum Lutetiae Calendis Maiis 1550. 


\section{Ad easdem virgines sorores Comes Alsinous}

Tempore quo verni radiantia lumina solis undique multiplici prata colore novant, ecce oblata mihi vernantia disticha centum, alterna docte disticha scripta manu.

Tunc subiisse meos omnes nova gaudia sensus

credite et immemorem pene fuisse mei.

$\mathrm{O}$ quoties sunt lecta mihi quotiesque relecta!

Lecta tenent animum, saepe relecta trahunt.

Macte tribus tres ingeniis! Sacra carmina vobis digna magis, quamvis haec quoque sacra sonant.

Pergite, Semorides, sub Apolline scribere Christo, dum vestrae aetatis flos tener iste viget, et sacram vestro capiti iam nectite laurum quam nequeat vobis detrahere ulla dies.

Ex Alsinoia nostra.

2-1 Tempore ... 2 novant: cf. Hessus, Sylv. 5.22.1-2: "Tempore quo tepidi vernantia lumina solis / florida milleno prata colore novant." (The epithet vernantia in Hessus' text reappears in Denisot's 1. 3; Denisot's radiantia lumina solis is from Ov. Trist. 2.325.)

3 ecce ... 6 mei: cf. Secundus, Ep. 1.10.1-4: "Nunquid ubi manibus sese tua litera nostris / obtulit $[\ldots]$ / tunc subiisse meum plenissima gaudia pectus / credis et immemorem pene fuisse mei?"

5 omnes ... sensus: Baptista Mantuanus, Sylvae 4.3.112. See Tertius et ultimus tomus poematum [...] Baptistae Mantuani ([Paris], 1513) [USTC 187233], f. 192r: "titillent omnes sua gaudia sensus."

7 O quoties ... 10 sonant: cf. Secundus, Ep. 1.5.7-9: "O quoties lecta illa mihi quotiesque relecta, / nec satiare oculos nec potuere animum. / Macte animo."

11 Pergite ... 14 dies: cf. Hessus, Sylv. 5.46.7-8: "Tu modo Pieridum sic ludere perge sub umbris, / dum tener aetatis flos viret iste tuae, / venturamque tuo capiti iam necte coronam / quam nequeant longi comminuisse dies." | Apolline ... Christo: a favorite expression in Hessus' works. See, for example, Sylv. 1.11.6; 3.8.94; 5.47.18.

Humanistica Lovaniensia 67.1 (2018), 143-208 
3. AnNae, Margaritae, IANAe, SORORUM VIRGINUM, HEROIDUM ANGLARUM, in mortem Divae MARGARITAE VALESIAE, Navarrorum reginae,

\section{Hecatodistichon}

\section{ANNA}

Haec sacra reginae cineres tegit urna Navarrae, urna tegens tenui grande cadaver humo.

\section{MARGARITA}

Regina hic, qua non alia est vel nomine maior vel pietate prior, Margaris alma iacet.

3 IANA

Margaris alma iacet, sed corpore. Mente nec olim dum vixit iacuit nec modo functa iacet.

\section{ANNA}

Divini vates, versus, non busta, parate, queis sita Margaridos molliter ossa cubent.

\section{MARGARITA}

Carminibus quicunque valent cantuque poetae Margaridem cantu carminibusque sonent.

6 IANA

Quae super egressa est sexus mentemque modumque, regina (heu) periit, si periisse potest.

\section{ANNA}

Corpus humum, sed mens coelum. Quod amabat utrunque iam tenet. Antiquis gaudet utrunque locis.

2 Regina ... prior: cf. Strozzi, Erot. 1.1.59-60 (f. 203r): "Summe ducum, quo non alius vel nomine maior / vel bello melior vel pietate prior."

4 queis ... cubent: cf. Hessus, Epicedia 3 C.3.2: "Hic sita Dureri molliter ossa cubant." Cf. Ov. Trist. 3.3.76: "molliter ossa cubent."

5 Carminibus ... sonent: cf. Hessus, Epicedia 4.123-124: "Carminibus quicunque valent et voce poetae / deplorant mortis tristia fata tuae."

6 Quae ... modumque: cf. Denisot's funerary plaque for Queen Marguerite, printed at the end of Sainte-Marthe 1550 (as in n. 35), 146: "et moribus sanctissimis et doctrina supra legitimum sexus sui morem ac modum praestantissimae." | regina ... potest: the verse reuses R, 4. Epicedium, 3-4 (cf. Hosington 1996 [as in n. 9], 148): "Rex regum Henricus [...], / heu, pietas periit, si periisse potest." Cf. Ov. Trist. 1.4.28: "si modo, qui periit, non periisse potest." 


\section{MARGARITA}

Idem reginae cineres atque ossa Navarrae, non idem claudit Spemque Fidemque lapis.

9 IANA

Quicquid ab Aeterno potuit mortalibus usquam esse boni aut sancti, Margaris obtinuit.

10 ANNA

Illa bono et sancto toties operata, bonoque et sancto fruitur perfruiturque Deo.

11 MARGARITA

Reginae in terris quicquid sol lumine lustrat quicquid et Oceanus proluit est tumulus.

12 IANA

Non haec reginam claudit brevis urna Navarrae. Claudere reginam tam brevis urna nequit.

\section{ANNA}

Felix, quae Sponso vigilans veniente reperta est, lampada non oleo deficiente suam.

\section{MARGARITA}

Adventus Christi donec tuba nuntiet horam qua licitum rursus sit rediisse iacet.

\section{IANA}

Perfossus paries non est. Vigil illa latronum usque sibi insidias caverat, usque suis.

8 cineres atque ossa: Verg. Aen. 5.787.

9 mortalibus usquam: Verg. Aen. 2.142.

10 perfruiturque Deo: Bourbon, Nugae, f. e8r: "Quod mortale fuit, parva requiescit in urna / corpus. Mens vivit perfruiturque Deo."

11 - 12 Reginae ... nequit: epigrams 11 and 12 form a unit. The verses paraphrase Giraldi, Poematia, 158: "Non haec quam spectas claudit brevis urna Manardum. / Claudere tam magnum nam brevis urna nequit. / Est ipsi tumulus quicquid sol lumine lustrat / et quicquid magnus proluit Oceanus."

13 lampada ... oleo deficiente: cf. More, Epigr. 75.9: "oleo lampas deficiente perit"; imitated in Bourbon, Nugae, f. g4r: "lampas deficiente oleo."

14 Adventus ... iacet: cf. Hessus, Epicedia 10.181-183: "Molliter exigua corpus requiescat in urna, / donec in hoc licitum sit rediisse tibi, / donec id adventus tuba nuncia suscitet horae." 


\section{ANNA}

Margaridis tumulo si non bona verba preceris, vel Christi ignarus vel male gratus homo es.

\section{MARGARITA}

Siqua Dei pura de relligione fideque promeruit laudem, Margaris illa fuit.

18 IANA

Hic, cui nostra parem prisci neque temporis aetas nec similem cernent saecla futura, iacet.

19 ANNA

Si moritur corpus, non gloria, nomen, honorque, nec moritur quicquid sancta Poesis habet.

\section{MARGARITA}

Quae Musis dare sueta suum cum fratre nitorem, cum Musis periit fratreque rege, soror.

\section{IANA}

Non alia quam qua felices lege perempta est. Ergo felicem quis periisse putet?

\section{ANNA}

Quam nec vel praesens vel postera nesciet aetas, occidit et loca quae saepe cupivit habet.

\section{MARGARITA}

Margaris, humano iam libera carcere, coeli nunc spatio fruitur liberiore sui.

16 Margaridis ... homo es: cf. Poliziano, Epigr. 80.1-2: "Hunc Domiti siccis tumulum qui transit ocellis, / vel Phoebo ignarus vel male gratus homo est."

18 Hic ... iacet: cf. Strozzi, Erot. 1.8.145-146 (f. 113r): "cui neque nostra parem neque prisci temporis aetas / vidit nec similem saecla futura ferent."

19 Si moritur ... honorque: cf. the concluding verses of an epitaph by Ioannes Bressanus Bergamensis in Erasmus, Catalogi, 116: "At tegitur corpus, sed nomen, gloria, honorque / clara micant."

22 Quam ... habet: Strozzi, Erot. 6.2, "Mustellae laus et epicedion", f. 175r: "Iam te nec praesens nec postera nesciet aetas, / aeternumque tuus nomen habebit honos." (not in Della Guardia's edition). Cf. Strozzi, Erot. 6.10.175-176: "Nunc quoque neu praesens neu postera nesciat aetas / qualis sub gelido marmore nympha cubet."

23 Margaris ... sui: cf. Hessus, Epicedia 10.163-164 (used more fully in R, 4. Epicedium, 243-244; cf. Jugé 1907 [as in n. 1], 61): "Ille quidem, tetro mortalis carcere liber / carceris [for corporis], astriferi possidet orbis opes." |fruitur liberiore: Claud. Carm. 20.10. 
24 IANA

Ergo perit, toties pia quae cantare solebat carmina, fatales saepe morata manus?

25 ANNA

Terrestris scripsit nobis sacra carmina. Iam nunc coelestis Christo carmina sacra canit.

26 MARGARITA

Dicite cum Paulo, "Dormit regina Navarrae." Dormit, sed certa surgat ut illa die.

27 IANA

Quo vigor ille animi? Quo regia corporis illa maiestas? Sancti quo decor oris abit?

28 ANNA

"Mortua mi facies et corporis horrida visu caetera, sed mentis pulchra figura meae est."

29 MARGARITA

Asclepi valeant valeantque Machaonis artes. Utitur haec Medico, non moritura, suo.

30 IANA

Det requiem cineri Dominus, conscendat et ipse spiritus aethereum venerat unde polum.

31 ANNA

Extinctum licet angusta stet corpus in urna, non tamen angusto limite fama volat.

32 MARGARITA

Hancne perisse putas, quam qua patet obstupet orbis et cuius nomen complet utrunque polum?

24 cantare ... manus: Hessus, Epicedia 4.21-22: "cantare solebat / carmina, fatales saepe morata manus."

27 Quo ... abit: cf. Strozzi, Erot. 6.2, "Mustellae laus et epicedion”, f. 174v: "Quo vigor ille animi? Quo strenua corporis illa / dexteritas abiit? Quo nitor ille tuus?" | decor oris: Ov. Fast. 2.774.

31 Extinctum ... volat: cf. Hessus, Epicedia 5.35-36: "brevi clausum est breve corpus in urna. / Fama manens pulsat solis utranque domum."

32 qua patet ... orbis: Ov. Trist. 4.9.20; 5.14.34. | nomen complet utrunque polum: from Veit Kopp, epitaph 9, in Erasmus, Catalogi, 113: "Hoc Desiderii tumulo conduntur Erasmi / ossa. Viri nomen replet utrunque polum."

Humanistica Lovaniensia 67.1 (2018), 143-208 
33 IANA

Margaridem quum mors, fieret ne aeterna, peremit, illam ex mortali reddidit indigetem.

34 ANNA

Corporeis toties pacem mens anxia rixis optavit. Tandem ut pace fruatur, obit.

\section{MARGARITA}

"Vixi," inquit, "satis atque super fatique peregi tempora. Nunc vitam dissoluisse iuvat."

36 IANA

Huius fama probam et sinceram publica vitam iactat. Habet certam publica fama fidem.

\section{ANNA}

Rapta est quum plures posset superesse per annos. Optima quaeque cadunt, pessima quaeque manent.

\section{MARGARITA}

Sueverat huc illuc terris peregrina vagari.

Pertaesum erroris quum foret, astra petit.

\section{IANA}

Quaeris cur studuit puram bene ducere vitam?

Ut bene supremum posset obire diem.

40 ANNA

Sub Christo vixit domino duce. Mortua Christo est sub duce. Sub Christo vitaque morsque fuit.

34 Corporeis ... obit: cf. Strozzi, Epigr., f. 87r: "Sperat enim a gravibus pacem mens anxia rixis, / at mala de placida iurgia pace timet."

35 Vixi ... tempora: cf. Veit Kopp, epitaph 15, in Erasmus, Catalogi, 114. In 1. 4 of the epigram, Kopp has Erasmus say: "Vixi satis, fati peregi tempora."

37 plures ... annos: cf. Hessus, Psalt. 21.7: "ut plures possit superesse per annos"; Hessus, Theoc. 18, f. G5r: "plures superesse per annos." | superesse per annos: Verg. Aen. 8.399.| Optima ... manent: cf. Hessus, Epicedia 2.80 (also used in R, 4. Epicedium, 74; cf. Jugé 1907 [as in n. 1], 60): "Tempore quam constant optima quaeque brevi."

39 Quaeris ... diem: cf. Tito Strozzi, Epitaphia, in Strozii poetae, f. 250v: "Sed meliora petens studuit bene ducere vitam / ut bene supremum posset obire diem.”

40 Sub Christo ... sub duce: perhaps suggested by Sainte-Marthe 1550 (as in n. 35), 109110: "Nunquid iure clamare possumus, "Beata Margarita, quae in Domino mortua est'." 
41 MARGARITA

Quid non illa habuit? Quid non fuit ante? Tamen nil tunc fuit aut habuit. Nunc habet estque aliquid.

42 IANA

Margaris ut moritur, tunc vitam vivere primum incipit. Est mundo mortua, viva Deo.

43 ANNA

O quoties dixit: "Nostrae longissima vitae tempora. Non vivam morte soluta, Deus?"

44 MARGARITA

Et virtute duce et duro comitante labore, in coelo princeps principe sede sedet.

45 IANA

Quaeso, quid in terris nisi dura, nisi aspera vidit? Quaeso, quid in coelis praeter amoena videt?

46 ANNA

Qualem divitibus, talem se semper egenis praestitit. Ergo illam dives inopsque gemunt.

\section{MARGARITA}

Nunc aula regina caret. Quid tum? Modo Christi et fruitur divum diva panegyribus.

41 Quid non illa ... fuit ante: cf. Hessus, Epicedia 11.51-52, on the death of Erasmus: "Nam quid non habuit? Quid non fuit ille, quod ipsae / fatales possent non timuisse deae?"

42 tunc ... incipit: combining Hessus, Epicedia 11.151, "vitam nunc primum vivit Erasmus", with Hessus, Epicedia 7.11-12 (also used in R, 4. Epicedium, 225-226), "Creditus interiisse tibi, nunc vivere primum / incipio."

43 O quoties dixit: Ov. Pont. 1.9.23. | morte solute: Ov. Her. 10.78.

44 Et virtute ... labore: cf. Cic. Fam. 10.3.2: "virtute duce, comite fortuna"; Erasmus, Adag. 4.10.47, in A. Wesseling (ed.), Opera omnia Desiderii Erasmi Roterodami, vol. 2.8 (Amsterdam, 1997), 246-247.

46 Qualem ... praestitit: cf. Hessus, Epicedia 10.49 (also used in R, 4. Epicedium, 181; cf. Jugé 1907 [as in n. 1], 61): "Qualem divitibus, talem se gessit egenis." 
48 IANA

In sua qui credit redituras corpora mentes, Margaridem credat non potuisse mori.

49 ANNA

Perdidit (o felix!) falsae mala gaudia vitae.

Invenit vitae gaudia vera novae.

50 MARGARITA

Mortua, sed Christo, est. Nunc vivit mortua Christo.

Nam tibi, Christe, mori, vivere, Christe, tibi est.

51 IANA

Ergo mori grave? Non. Sic, sic iuvat ire fidelem, et dixit moriens, "Sic quoque non morior."

52 ANNA

"Mortua sum, vitae sed spes est una prioris, quod me cum Christo vita secunda manet."

\section{MARGARITA}

Exuit illa sui mortalia corporis arma.

Induit arma animae non moritura suae.

\section{IANA}

"Quid moror in terris, naturae filia, tantas

si mundus caussas cur fugiatur habet?"

48 In sua ... mentes: cf. Fausto Andrelini's metrical paraphrase of the Apostle's Creed, originally published as the concluding elegy of book 2 in his Elegie (Paris, [ca. 1494]), f. e5r; reprinted, for example, in his De virtutibus cum moralibus tum intellectualibus carmen dignissimum. Elegiae quaedam castiores sanctioresque (Strasbourg, 1509) [USTC 681888], f. d1v: "In sua confiteor redituras corpora mentes." | Margaridem ... mori: cf. Hessus, Epicedia 3 C.2.2: "Certum est Durerum non potuisse mori."

49 Perdidit ... novae: cf. Hessus, Epicedia 10.127-128 (also used in R, 4. Epicedium, 215-216; cf. Hosington 1996 [as in n. 9], 150): "Perdidit Ebnerus falsae mala gaudia vitae. / Invenit vitae gaudia vera novae."

51 Sic, sic iuvat ire: Verg. Aen. 4.660. | et dixit ... morior: from Hessus, Epicedia 3 C.4.6, where Death speaks to Albrecht Dürer: "Et dixit, 'Moriens sic quoque non moreris'." Cf. Verg. Buc. 2.38: "et dixit moriens."

53 Exuit ... suae: cf. Hessus, Epicedia 10.129-130 (also used in R, 4. Epicedium, 217118; cf. Hosington 1996 [as in n. 9], 150): "Exuit arma sui mortales corporis artus. / Induit arma animae non moritura suae."

54 Quid moror in terris: cf. Cic. Rep. 6.15 and Macr. Somn. 1.13.3: "quid moror in terris." 
55 ANNA

Ussit et exarsit. Quidni? Libabat amica oscula, sed Christo deliciosa suo.

56 MARGARITA

Quid non cogit amor Christi? Sese ipsa negavit ne Christum neget huic neve neganda foret.

57 IANA

Occuluit roseos Christo addictissima vultus, quum sibi supremum sensit adesse diem.

58 ANNA

"Quid trepido, si fida mei est custodia Christus? Quid trepido? Mihi mors vivere, vita mori."

59 MARGARITA

Spiritui caro quae toties contraria cessit, litigiosa fuit res. Sine lite modo est.

60 IANA

"Auxilii nunc arma mei clypeumque salutis Christus habet. Mortis non ego tela tremo."

61 ANNA

Tartare, nulla tua est victoria. Vicit Iesus, et Mors quo stimulo possit obesse caret.

62 MARGARITA

"Vivere triste mihi est lucrumque mori." Haec ita demum fata, animam Patri reddidit, ille tulit.

63 IANA

"Si mea mors Christi fuerit victoria Morsque sic absorpta, mori me potuisse putas?"

55 Ussit et exarsit: Strozzi, Epigr, f. 84v (passionate love): "Ussit et exarsit flammaeque haud gnarus acerbum / flevit."

56 Quid ... Christi: cf. Hessus, Eccles. 231: "Quid non cogit amor nummi?"; also cf. Mart. Epigr. 5.48.1: "Quid non cogit amor?"

57 Occuluit ... diem: cf. Strozzi, Epigr., f. 85v: "Occuluit roseos ficta sub imagine vultus"; Poliziano, Eleg. 7.174: "extremum sentit adesse diem."

59 litigiosa ... modo est: cf. Strozzi, Epigr., f. 96r: "Res sine lite mea est, litigiosa tua est." 60 Auxilii ... habet: cf. Hessus, Psalt. 7.49-50: "Auxilii Deus arma mei clypeumque salutis / solus habet." 
64 ANNA

"Dum mihi vita datur, sequitur mors inde. Sed ecce vita tristitiam comparo, morte lucrum."

\section{MARGARITA}

"Ceu novus exuviis serpens revirescit ademptis, sic nova me posito corpore forma manet."

66 IANA

"Quantum erat in me animi, Christo servivit. Ob idque sum regina magis quam modo viva fui."

67 ANNA

"Dum muto in terris vitam pro morte, repente pro morte in coelis vita secunda datur."

68 MARGARITA

Quaeritis in terris cur nolit vivere? Vitae in coelum fecit mors melioris iter.

69 IANA

"Ille Deus, Deus ille Pater, promisit Iesum, quem dedit. Eius mors vitaque facta mea est."

70 ANNA

"Ille Puer natus nobis et mortuus ille, nonne iterum vivit? Sic ego vivo iterum."

71 MARGARITA

Ceu postliminio primos remeavit in ortus aetheris. Exilium totus hic orbis erat.

72 IANA

Quam non mutarunt nec laeta nec aspera mentem, iam fruitur laetis aspera nulla timens.

65 Ceu novus ... ademptis: cf. Ercole Strozzi, Elegiae, in Strozii poetae, f. 62v: "Ceu novus exuviis serpens revirescit ademptis."

67 repente ... datur: cf. Voulté, Epigr., 190 (an epitaph for the Dauphin François, also used in $\mathbf{R}, 4$ c. De eodem): "A regno, patre rege, trahunt dum fata, repente / regnum aliud, regem dant quoque fata patrem."

72 Quam ... mentem: cf. Baptista Mantuanus, Epigrammata ad Falconem 16.1: "Cur sors Falconem nec laeta nec aspera mutat?" See Secundus operum B. Mantuani tomus ([Paris], 1513) [USTC 187231], f. 139r. 
73 ANNA

Spe prius usa Fideque almaque sorore duarum, Speque Fideque, nihil credit et optat, amat.

74 MARGARITA

Lilia gestabat tria, regum insignia. Quidni?

Regia ter, regum sponsa, soror, soboles.

75 IANA

Reginae ad superos aditum mens aequa fidesque et virtus, pietas relligioque dedit.

76 ANNA

Nunc quia conditio vitae est mutata prioris, dicite, "Vita fuit quae prior umbra fuit."

77 MARGARITA

Si bona praecessit per Christum vita fuitque mors bona, quam repetit vita secunda bona est.

78 IANA

Aeternum felixque vale, decus addita coelo, quam pietas iungit conciliatque Deo.

79 ANNA

Felices animae, quibus it comes illa Navarrae regina, aeterna candida tota stola.

80 MARGARITA

Hanc omni pietate colat, pietate precetur, qui pietate illi se studet esse parem.

81 IANA

"Arrabo, quem fuso dederat mihi sanguine Christus, in coelo merces nunc mihi tota datur."

73 amat 1551 habet 1550

75 Reginae ... dedit: cf. Strozzi, Erot. 3.4.79-80 (f. 131v): "Adde quod ad superos aditum mens aequa fidesque / et virtus praestans relligioque dedit."

76 Nunc ... fuit: cf. Hessus, Epicedia 7.9-10 (also used in R, 4. Epicedium, 227-228): "Quam bene conditio vitae est mutata prioris, / quae, mihi si quis ad hanc conferat, umbra fuit."

78 Aeternum ... coelo: from Giraldi, Poematia, 116: "Aeternum felixque vale, decus addita coelo." Cf. Verg. Aen. 11.98 and 8.301.

79 Felices ... Navarrae: cf. Sannazaro, Epigr. 1.10 .7 (in an epitaph): "Felices animae, quibus is comes ipsa per umbras."

Humanistica Lovaniensia 67.1 (2018), 143-208 
82 ANNA

"Meta mei cursus Christus fuit, unde brabeum promissum et stadii praemia certa fero."

83 MARGARITA

"Et Carne et Mundo Sathanaque et Morte subactis, morte mea vitae parta trophaea gero."

84 IANA

"Fratre meo carui. Quid erat mihi charius illo?

Quid si iterum liceat iam mihi fratre frui?"

85 ANNA

Desinite, artifices, caelare hanc, pingere. Pinxit, caelavit scriptis se satis illa suis.

86 MARGARITA

Quis Speculum illius non admirabitur, in quo vera Dei effigies illa refracta datur?

\section{IANA}

Mille patent causae, causas si mille requiras, cur diva ex omni parte beata modo est.

\section{ANNA}

Ante fuit fragili, nunc est redimita corona aeterna, aeterni signa secuta Ducis.

\section{MARGARITA}

Ter conclamavit venerabile nomen Iesus.

Ter conclamati tota recepta sinu est.

85 Desinite ... suis: the distich goes back to Sainte-Marthe 1550 (as in n. 35), 122: "Neminem puto vel in dicendi facultate tam feliciter versatum esse vel ad Homericam dignitatem aut ad Maronianam gravitatem tam prope unquam accessisse ut melius possit Margaritam ad vivum pingere quam suo se ipsa penicillo pinxit, nimirum scriptis suis ingenium, eruditionem, pietatem, ac mores plane eius sic referentibus ut iam non sit opus statuas illi erigere."

87 Mille ... requiras: cf. Hessus, Sylv. 9.26.33: "Mille alias taceo caussas, si mille requiras."

89 Ter conclamavit ... sinu est: cf. Sainte-Marthe 1550 (as in n. 35), 109, where SainteMarthe describes Marguerite's death: "Moribunda voce clamavit, 'Iesus, Iesus, Iesus', cumque haec dixisset spiritum emisit." Cf. also Marguerite's epitaph at Sainte-Marthe 1550 (as in n. 35), 145: "Proxima sed morti, ter conclamavit 'Iesus'. / Deinde animam summo reddidit ipsa Iovi." It may be added here that Sainte-Marthe's epitaph for Marguerite at Sainte-Marthe 1550 (as in n. 35), 144, "Abstulit hora unam quam non perfecerat hora. / Maius opus fuerit, si dabit hora parem", inspired Denisot's epigram about the two Marguerites in Denisot 1551 (as in n. 6), f. k8r: "Margaris extincta est quam nobis abstulit hora. / Quid, rogo, si nobis et dedit hora parem?" 
90 IANA

Vivit, io, vivit, somnoque quiescit amico, quae vigil est somno vivaque morte sua.

91 ANNA

Ingredere, o felix Regina, in prata salutis, qua ducit niveas signifer Agnus oves.

\section{MARGARITA}

Candida candenti fulgens in veste sacerdos, iam non facta manu templa Deumque cole.

93 IANA

Fronte Dei vivi gestas insigne sigillum. Laedere signatam iam mala nulla queunt.

94 ANNA

Incipe ferre manu palmae victricis honorem, vel quia vicisti vel quia fortis eras.

\section{MARGARITA}

Ante throni iam stas arcem, iam Numen adoras, iam clamas, "Soli qui sedet arce salus!"

\section{IANA}

Iam tibi vera manu libamina, thuris acerra iam veri, purae, non sine mente, preces.

\section{ANNA}

Non sities, non esuries, non frigus et aestum iam metues, superis addita diva choris.

\section{MARGARITA}

Millia mille tibi sanctorum atque altera mille millia, mille iterum millia iuncta sedent.

91 Ingredere, o felix: Hessus, Luth. 1.81: "Ingredere, o, felix"; cf. Verg. Aen. 8.513. | qua ducit ... oves: from Hessus, Epicedia 6.114: "Qua niveas ducit signifer Agnus oves."

92 Candida candenti: Bourbon, Nugae, f. g2r: "Candida candenti gestis nive ludere virgo"; cf. Ov. Am. 3.3.5: "candida, candorem roseo suffusa rubore." | fulgens in veste sacerdos: Sannazaro, Virg. 1.262: "aurata fulgens in veste sacerdos"; cf. Verg. Aen.12.169: "in veste sacerdos."

94 ferre ... honorem: cf. Secundus, Ep. 2.6.52: "Quis ferret primum palmae viridantis honorem?"

97 superis addita diva choris: cf. Sannazaro, Epigr. 3.2.2: "Quarta Charis, decima es mihi Pieris, altera Cypris, / Cassandra, una choris addita diva tribus." The epigram is also used in a distich attributed to Denisot's beloved Valentina. See note at R, 3. Aegloga, 102-103. 
99 IANA

Ad vivos fontes iam Dux tibi, iam praeit Agnus.

Iam vivi Panis mensa parata tibi est.

100 ANNA

Gaudia quis numeret sponsae Sponsique perennis, quos iungit thalamis Lux sine fine suis?

101 MARGARITA

Oscula quis numeret sancte libata duobus deliciasque animae deliciasque Dei?

102 IANA

Quis numeret plausus ex omni parte sonantes spirituum aeterni quos tenet aula Dei?

103 ANNA

Hymnus erit sanctus sacras Hymenaeus ad aures. Carmen erit "Sanctus" ter geniale sonans.

104 MARGARITA

Iam cane, "Lux sit, honor, sapientia, gratia, virtus, sicut erat, nunc est, semper eritque, Deo."

FINIS

The Ohio State University, Columbus vredeveld.1@osu.edu

99 mensa parata tibi est: Mart. Epigr. 14.218.2, as quoted, for example, in Lorenzo Valla, De Latina elegantia libri VI (Paris, 1533) [USTC 181428], 34 [1.14]; Niccolò Perotti, Соrnu Copiae Latinae linguae (Basel, 1536) [USTC 625546], 67. 